\title{
Sediment Production and Yield from an Alluvial Gully in Northern Queensland, Australia
}

\author{
Shellberg, J.G. ${ }^{{ }^{*}}$; Brooks, A.P. ${ }^{1}$; Rose, C.W. ${ }^{1}$ \\ ${ }^{1}$ Australian Rivers Institute, Griffith University, Nathan, Queensland, Australia 4111 \\ * Corresponding Author: \\ Email address: j.shellberg@griffith.edu.au (J. Shellberg). \\ Address: 1.19, Building N13, 170 Kessels Road, Nathan, Queensland, Australia 4111 \\ Tel: +61-401-926-288 (voice), +61-07-3735-7615 (fax)
}

\begin{abstract}
:
Sediment production, transport and yield were quantified over various time scales in response to rainfall and runoff within an alluvial gully (7.8 ha), which erodes into dispersible sodic soils of a small floodplain catchment (33 ha) along the Mitchell River, northern Australia. Historical air photographs and recent GPS surveys and LiDAR data documented linear increases in gully area and volume, indicating that sediment supply has been relatively consistent over the historic period. Daily time lapse photography of scarp retreat rates and internal erosion processes also demonstrated that erosion from rainfall and runoff consistently supplied fine washload $(<63 \mu \mathrm{m})$ sediment in addition to coarse lags of sand bed material. Empirical measurements of suspended sediment concentrations (10,000 to $>100,000 \mathrm{mg} / \mathrm{L}$ ) and sediment yields (89 to 363 t/ha/yr) were high for both Australian and world data. Total sediment yield estimated from empirical washload and theoretical bed material load was dominated by fine washload $(<63 \mu \mathrm{m})$. A lack of hysteresis in suspended sediment rating curves, scarp retreat and sediment yield correlated to rainfall input, and an equilibrium channel outlet slope supported the hypothesis that partially or fully transport-limited conditions predominated along the alluvial gully outlet channel. This is in contrast to sediment supply-limited conditions on uneroded floodplains above gully head scarps. While empirical data presented here can support future modelling efforts to predict suspended sediment concentration and yield under the transport limiting situations, additional field data will also be needed to better quantify sediment erosion and transport rates and processes in alluvial gullies at a variety of spatial and temporal scales.
\end{abstract}

Keywords: alluvial gully erosion, gully scarp retreat, suspended sediment concentration, sediment yield, sediment transport-limited. 


\subsection{Introduction}

Alluvial gullies are defined as incisional fluvial features entrenched into alluvium not previously incised since initial deposition (Brooks et al., 2009). Alluvial gullies have been inconsistently described and quantified in the literature as valley-bottom gullies, bank gullies, ravines, fan and finger gullies, and alluvial breakaways depending on their location in Australia (Simpson and Doutch, 1977; Payne et al., 1979; Condon, 1986; Pickup, 1991; Pringle et al., 2006; Brooks et al., 2008; 2009; McCloskey, 2010), India (Haigh, 1984; Singh and Dubey, 2000; Yadav and Bhushan, 2002), the United States (Brice, 1966; Piest et al., 1975), Europe (Poesen, 1993; Vandekerckhove et al., 2000) and Africa (Oostwoud Wijdenes and Bryan, 2001). Only a handful of key studies have empirically quantified sediment yields or erosion processes from alluvial gullies over time (e.g. Piest et al., 1975; Bradford and Piest, 1980; Thomas et al., 2004; Singh and Dubey, 2000; Oostwoud Wijdenes et al., 2000; Oostwoud Wijdenes and Bryan, 2001; Vandekerckhove et al., 2001; 2003; Shellberg et al., 2013). This is in contrast to the abundant literature on sediment yield from hillslope, colluvial, or ephemeral gullies and soft-rock badlands (e.g., citations within Prosser and Winchester, 1996; Poesen et al., 2003; Poesen et al., 2006). Preliminary data in the Mitchell River catchment in northern Australia suggest that alluvial gullies are a major sediment source (Brooks et al., 2008; 2009; Rustomji et al., 2010; Shellberg, 2011; Caitcheon et al., 2012). However, the dearth of empirical data and theoretical models on erosion and sediment yield from these gullies limits the creation of robust and detailed sediment budgets for the large river floodplains of northern Australia where alluvial gullies are widespread.

To further the understanding of alluvial gully erosion rates and processes, one small alluvial gully catchment along the Mitchell River in northern Australia was chosen for detailed empirical analysis. The specific objectives of this research were to empirically quantify 1) rainfall and water runoff, 2) sediment production at the gully head scarp, and 3) sediment concentrations, transport and yield over various time scales in comparison to regional, national and international data. 


\subsection{Material and Methods}

\subsubsection{Study area}

The gully study catchment (WPGC2a) is located in remote northern Queensland, Australia (16²8’16”, 14346’36”; Shellberg et al., 2013). WPGC2a is one alluvial gully of thousands delineated and described by Brooks et al. (2008; 2009) on the Mitchell River fluvial megafan, where alluvial gullies cover an area $>129 \mathrm{~km}^{2}$. WPGC2a has an internal gully area of 7.8 ha (circa 2008) of exposed soils below the active head scarp, and a 33 ha catchment surface area dominated by flat floodplain topography (Figure 1). It is one tributary catchment of a large complex of alluvial gully erosion ( 100 ha) that erodes into the high floodplain of the Mitchell River 1 to $2 \mathrm{~km}$ from the river thalweg (Shellberg et al., 2013).

Rainfall and runoff dominate erosion at WPGC2a (Shellberg et al., 2013), with only infrequent river backwater and overbank flood inundation compared to other gullies further downstream on the megafan. The tropical monsoon climate is highly seasonal, with $>80 \%$ of its annual rainfall (mean 1015; range 500 to $2100 \mathrm{~mm}$ ) falling between December to March. Rainfall intensity and erosivity (Rfactors) are moderately high, as are potential and actual evapotranspiration (Shellberg et al., 2013).

The alluvial silt/clay soils of WPGC2a are situated on a gradient of coarser, lower, and more active floodplain surfaces towards the Mitchell River (sands and gravels capped by silt) and finer, higher, and older silt/clay floodplains distally, which WPGC2a is actively eroding into. These Pleistocene redand yellow-earths are dense in bulk (> $1800 \mathrm{~kg} / \mathrm{m}^{3}$ ), hard-setting during the dry season and between storm events, alkaline at depth, and sodic (ESP > 6) (Shellberg et al., 2013). These sodic soils are highly prone to soil dispersion, loss of the thin A-horizon, scalding, and reduction of surface infiltration capacity, which accelerate surface and gully erosion. The only partial protection these soils have from the intense tropical rainfall, when un-vegetated, comes from patchy surface lags of pisoliths of ferricrete and calcrete, which readily form on the surface of exposed gullies after initial soil mottles and solutes permanently oxidize (Pain and Ollier 1992; Shellberg 2011).

Insert Figure 1 Approximately Here. 
The dominant land use for the area is low density cattle grazing ( 1 beast/20 ha on average) across savanna woodlands and grasslands (Arnold 1997). Cattle grazing intensity (1 beast/8 ha) and impacts (grass cover, soil disturbance, tracks/pads, weeds) are heavily concentrated along waterway frontages or riparian zones of main rivers and creeks, where animals congregate for water and feed during the long dry season. Many of the alluvial gullies across the Mitchell megafan initiated post-European settlement during the period when cattle numbers increased significantly from the 1880's onwards (Shellberg et al., 2010; Shellberg 2011). Gully initiation points were located at relatively steep slopes of stream banks, rounded precursor gullies on stream banks, and/or within un-channelled floodplainhollows, which evolved into large alluvial gullies that consumed the relatively flat high floodplain (Brooks et al., 2009; Shellberg 2011; Shellberg et al., 2013).

\subsubsection{Gully area and volume change}

To measure head scarp retreat rates and gully area change over recent times, the head scarp location around WPGC2a was surveyed annually between 2006 and 2010 using a differential global positioning system (GPS) with $\pm 50 \mathrm{~cm}$ accuracy (Trimble with Omnistar HP) (Brooks et al., 2009). For area change over the historic period, georeferenced air photographs from 1949 and 1960 were used to estimate historic scarp locations $( \pm 2 \mathrm{~m})$.

For more detailed recent change detection at a $100 \mathrm{~m}$ index scarp section $(2.7 \%$ of the total $3700 \mathrm{~m}$ scarp perimeter of WPGC2a), a digital time-lapse camera was mounted on a stable tree and used to take oblique daily photographs of the scarp location between 2009 and 2011 (Figure 1a). Digital photographs (2848 x 2136 pixels, 6 MP) were internally rectified to each other in a GIS using ground control points. The gully scarp edge was digitized daily after intervals of observable change. Due to the oblique angle, only a relative change in gully area at the scarp edge could be measured, which was calculated as the percentage of daily change divided by the total change over the period of record. To estimate actual planform change, the percentage of daily change divided by the total change was multiplied against the horizontal area change measured during annual GPS surveys (Shellberg et al., 2013). 
For gully volume estimates, Light Detection and Ranging (LiDAR) topographic data were collected in 2008 and used to create a $1 \mathrm{~m}^{2}$ ground-surface digital elevation model (DEM) (Figure 1a). To estimate the pre-gully erosion surface, an inverse distance weighted (IDW) algorithm (power 2; 500 point search radius) was used to interpolate across the eroded gully from elevation data at uneroded points along the external perimeter and internal pedestals. The 2008 gully volume was calculated by subtracting the LiDAR DEM elevations from the interpolated pre-gully surface elevations. Earlier gully volume estimates (1949, 1960, 2006, 2007) were similarly calculated, but the DEMs were clipped to gully area extent for those periods. This method assumes a vertical head scarp, complete export of sediment, and no changes in gully floor storage, which are first order assumptions for a gully eroding into dispersible silts and clays. Additional volume changes into 2009 and 2010 were estimated from the measured area change multiplied by a measured $1.5 \mathrm{~m}$ average scarp depth. LiDAR data were also used to plot multiple longitudinal profiles of the main gully thalweg and major tributaries to define gully form and elucidate erosion processes.

\subsubsection{Hydrological measurements}

Rainfall was measured at WPGC2a with an automated tipping bucket during water year (October to September) WY 2009 and WY 2010. A continuous water stage gauge was operated at 15 min intervals to measure water depth (D) in a semi-confined sand-bed channel reach at the bottom of the WPGC2a

(Figure 1; Figure 2). This gauge is located just upstream of known Mitchell River backwater conditions during major overbank floods, which was measured by a downstream stage gauge (Shellberg et al., 2013).

Measurements of discharge (Q) were made on the rising and falling stages of several flood events using standard current meter techniques, which were supplemented with indirect estimates of Q using slope-area techniques (Rantz, 1982). Before, during, and after each wet season, elevation crosssections, thalweg profiles, and peak flood marks were surveyed over a distance greater than 10 channel widths. A 1-D HEC-RAS hydraulic model (Brunner, 2010) was created for the reach for several slightly different boundary conditions. The model was calibrated using direct D and Q measurements. Calculated composite Manning's n roughness values ( $\sim 0.035)$ were used in the model 
to predict discharge values at high stages. D-Q rating curves used both measured and modelled data. Errors in Q from current meter measurements were taken as $\pm 10 \%$ while slope-area estimates were $\pm 20 \%$.

Insert Figure 2 Approximately Here.

\subsubsection{Sediment load definitions and approaches to estimation}

Fundamental to any sediment transport/yield research is the definition of how sediment load is transported, measured in the field, and/or modelled, by source or mode of transport (Knighton, 1998; Hicks and Gomez, 2003):

- $\quad$ Total particle load = bedload + suspended load (i.e., load by mode of transport)

- $\quad$ Total particle load = bed material load + washload (i.e., load by source)

For this study, field efforts concentrated on the measurement of suspended load at a gauge station (load by mode of transport). Sand bedload was not measured in this study. Thus, direct measurements of total load by mode of transport could not be made. Due to the difficulty in theoretical modelling just sand bedload transport along or near the bed separated from bed material in suspension, we used readily available models of theoretical bed material load (Ackers and White 1973; Yang 1973; Yang and Wan 1991) to estimate sediment transport sourced from the local bed material and transported both along the bed and in suspension. To estimate total load by source, we empirically estimated washload from measured suspended load by adopting the frequently used but arbitrary washload cutoff of $<63 \mu \mathrm{m}$ (sand vs. silt/clay), to which we added theoretical estimates of bed material load for bed particles $>63 \mu \mathrm{m}$.

\subsubsection{Empirical measurements of suspended load}

Due to the remote location, single-stage suspended-sediment samplers (U.S. U59C; Colby, 1961) were installed across a cross-section at staggered elevations, in order to automatically collect suspended sediment concentration (SSC) samples from specific points in the cross-section during rising stage conditions during WY 2009 and WY 2010 (Colby, 1961; Edwards and Glysson, 1998). Additional 
width- and depth-integrated samples of mean SSC were collected manually by wading during several flood events in WY 2010 using an isokinetic US DH-48 SSC sampler and the equal-width-increment method (Edwards and Glysson, 1998). The DH-48 sampler does not sample the near bed zone $<9 \mathrm{~cm}$ above the bed, which constitutes the bedload and unsampled zones. All samples were analysed using the SSC analysis protocol of the total sample volume via evaporation and dissolved salt correction (ASTM, 2002), which avoided negative sand biases associated with sub-sampling (i.e., TSS protocol; Gray et al., 2000). Error in SSC laboratory measurements were taken as $\pm 1 \%$.

Suspended sediment loads were calculated as the product of Q and SSC, where SSC was predicted from Q-SSC rating curves and Q predicted from D-Q curves for discrete time intervals. The total standard error $\left(\delta_{T}\right)$ relative to the sediment load $(\bar{T})$ was calculated as:

$$
\frac{\delta_{T}}{\bar{T}}=\sqrt{\left(\frac{\delta_{Q}}{\bar{Q}}\right)+\left(\frac{\delta_{S S C}}{\overline{S S C}}\right)+\left(\frac{\delta_{Q \propto D}}{\overline{Q \propto D}}\right)+\left(\frac{\delta_{S S C \propto Q}}{\overline{S S C \propto Q}}\right)}
$$

where $\delta_{Q}$ is the standard error in field Q measurement using either current meter methods (WY 2010, $\delta_{Q} / Q=0.10$ ) or slope-area methods (WY 2009, $\delta_{Q} / Q=0.20$ ), $\delta_{S S C}$ is the laboratory error in SSC measurement ( $\delta_{S S C} / S S C=0.01$ ), $\delta_{Q \propto D}$ is the standard error between the Q and D relationship, and $\delta_{S S C \propto Q}$ is the standard error between the SSC and Q relationship.

\subsubsection{Particle size distributions}

\subsection{6.a.1 Suspended load particle size}

The naturally high dispersibility of the sodic soils at the WPGC2a gully head scarps and internal gully surfaces promoted the disaggregation of any soil aggregates into their particle state. Stream turbulence and agitation along flow paths from source to SSC collection points also promoted full dispersion. Therefore for comparative consistency, sediment particle size distribution was analysed rather than aggregate size distribution, which in the case of these dispersible soils should provide a good approximation to the real state of transported sediment. 
SSC samples collected during flood events were wet sieved at $63 \mu \mathrm{m}$ to determine the percent sand ( $>63 \mu \mathrm{m})$ and silt/clay $(<63 \mu \mathrm{m})$ contributions to the total suspended sediment concentration. This cut-off was also used to estimate the proportion of washload to total suspended sediment load. More detailed particle size distributions were measured in duplicate on SSC samples collected during widthand depth-integrated sampling, using a Coulter Multisizer following the methods of McTainsh et al. (1997). For particles between $1 \mu \mathrm{m}$ and $256 \mu \mathrm{m}$, a four tube Coulter Multisizer analysis was conducted within a sodium hexametaphosphate liquid electrolyte, while the \% of total sediment by dry weight $>256 \mu \mathrm{m}$ was measured by wet sieving. Any soil aggregates not already dispersed by the initial erosion and transport processes, and subsequent SSC particle size splitting via wet sieving, would have been fully dispersed in the Coulter analysis liquid electrolyte.

Suspended-sediment particle-size distributions were converted to settling velocity distributions using the relationships in Cheng (1997). The mean settling velocities ( $\bar{\phi}$ ) derived from the suspended sediment distributions were correlated to respective water discharges (Q) during SSC collection, which were used in conjunction with sediment rating curves to define changes in suspended sediment properties with increasing discharge.

\subsection{6.a.2 Source material particle size}

Bed material in the sand-bed channel near the gauge (Figure 1) consisted of disaggregated mineral sands and fragments of ferricrete and calcrete. The bed material particle size distribution was measured from bulk samples (>1 kg) using wet sieving at half phi intervals down to $38 \mu \mathrm{m}$.

The major source materials for finer sediment and washload within the WPGC2a gully are the sodic silt/clay soils at gully scarps. For these soils, the Coulter Multisizer and sodium hexametaphosphate were again utilized to measure disaggregated particle size distributions to ensure comparability with the suspended sediment particle size analysis above. Nine sediment samples from three vertical scarp profiles and three depths $(30,100,200 \mathrm{~cm})$ were analysed. Duplicate analyses were conducted to ensure consistency of results. The average particle size distribution of all samples was used to characterize material sourced from gully scarps. Additionally, one sample from the surface of an 
actively accreting gully inset-floodplain near the gauge was used to quantify the size distribution of recent deposition.

\subsubsection{Theoretical estimates of total bed material load}

For a theoretical estimate of the total bed material load (bedload + suspended bed material), the empirically-calibrated equations of Yang (1973) and Ackers and White (1973) were employed. These models estimate the average bed material load concentration, regardless of transport mechanism of bed material along the bed or in suspension. The empirical D-Q relationship and cross-section data were used to estimate hydraulic parameters in the models at discrete time intervals, along with Q for load estimation in conjunction with modelled concentrations. Initially, the full particle size distribution of bed material was used to simply estimate a median $\left(\mathrm{d}_{50}\right)$ particle size for model use, in addition to using equations in Cheng (1997) to estimate mean settling velocity. As a more robust alternative, transport concentrations using the Yang (1973) model were computed by size fraction (12 classes) of a truncated particle size distribution $(>63 \mu \mathrm{m})$ to calculate a weighted sum of particle size concentrations (Yang and Wan 1991).

\subsection{Results}

\subsubsection{Gully area and volume change}

The area of WPGC2a had increased 7.6 times its initial 1949 size by 2010 (Figure 1a; Table 1). The trend in area was linear $\left(r^{2}=0.99\right)$, but the relationship is weakened by lack of data between 1960 and 2006. Recent annual GPS survey data at WPGC2a continued to measure increased area growth (Table 1; Figure 3), but area error margins often overlapped. This uncertainty was a result of survey error $( \pm 50 \mathrm{~cm})$ and overlap along slowly retreating inter-lobe zones of the scarp, compared to more active concave lobes (in planform) where distinct annual change was evident (Figure 3; Brooks et al., 2009; Shellberg et al., 2013). However over longer decadal scales, the entire gully scarp eventually retreated as one front when active lobes merged, disconnected interfluves were abandoned, and these remnant pedestals weathered in situ. 
Before 1949, the planform shape of WPGC2a was predominantly linear as one main headcut progressed upstream into an unchannelled floodplain hollow (Figure 1a; Shellberg 2011). This is also a pattern seen recently at incipient gullies adjacent to WPGC2a using a location-for-time substitution (Figure 1a; Brooks et al. 2009). Subsequently as the gully matured and more dispersible sub-soils were uncovered at depth and distally, the gully planform expanded in width as much as length and developed into an amphitheatre form (sensu Brooks et al. 2009) with a tortuous scarp front, individual globular lobes of activity, and less active inter-lobe zones (Figure 1a; Figure 3). As gully area expanded, the perimeter of the active scarp also increased, but the ratio of area to perimeter did not stay constant (Table 1). The mean retreat rate (area/perimeter) and mean depth (volume/area) subsequently decreased, as the perimeter expanded in a tortuous fashion and the erosion wedge (and scarp height) decreased, respectively. The decrease in gully depth and scarp height with advancement is highlighted by longitudinal profiles derived from LiDAR (Figure 4). The profiles also highlight equilibrium slope of the main channel outlet and the erosion wedge for future gully expansion.

Gully volume also increased at a linear rate $\left(r^{2}=0.99\right)$, suggesting that changes in area likely dominate volumetric sediment yield if the volumetric calculation assumptions are true. However this trend is also weakened by lack of data between 1960 and 2006. The estimated scarp erosion yield (t/yr) decreased over time, but this trend is influenced by the overlapping error margins around recent GPS data. When only the 1949, 1960, and 2008 air photos are used over much longer time intervals, along with the 2008 LiDAR data for volume calculation, the estimated long-term sediment yields overlap within error margins (Table 1). These yield data provide an order of magnitude estimate of sediment production at the gully scarp to compare to gully gauge data.

Insert Table 1 Approximately Here.

Daily delineation of index scarp locations from oblique photographs demonstrated that the total scarp retreat was the cumulative sum of numerous and variable daily changes over each wet season, most often as discrete failures of overhanging soil blocks. Both direct rainfall and infiltration-excess runoff dominated scarp retreat at WPGC2a, in contrast to groundwater seepage and pore water pressure (Shellberg et al., 2013). Shallow overland flow from the low-gradient vegetated floodplain above the 
scarp was relatively clear compared to the turbid water runoff following erosion on the scarp face, indicating that ungullied parts of the catchment are not major sources of sediment. However, the relatively flat floodplain catchment above the scarp did contribute much infiltration-excess water runoff to the scarp face, enhancing erosion there in addition to direct rainfall erosion. Oblique changes in area at the index scarp, corrected to planform area, showed strong correlations to 24-hr rainfall total $\left(r^{2}=0.77\right)$ (Figure 5). Detectible changes in scarp location did not occur until the 24-hr rainfall exceeded at least $10 \mathrm{~mm}$. The 24-hr rainfall total metric best predicted daily scarp retreat compared to other calculated rainfall metrics (Shellberg et al., 2013). In total, these data demonstrate that actively eroding gully scarps are major and consistent sources of fine and coarse sediment to the gully network, in addition to already exposed soils internal to the gully area.

Insert Figure 3, Figure 4, and Figure 5 Approximately Here.

\subsubsection{Empirical estimates of suspended load and washload}

Rating curves of water depth vs. discharge for WY 2009 and WY 2010 (Figure 6) estimated that peak Q during WY 2009 exceeded 1.5 m³/s while WY 2010 peaks were typically less than $1.0 \mathrm{~m}^{3} / \mathrm{s}$ (Figure 7). Peak events commenced rapidly following intense convective rainfall, with typical flow durations of 2 to 3 hours (e.g., Figure 11). Rainfall and runoff volumes in WY 2010 were approximately half that of WY 2009, with runoff coefficients one-quarter of rainfall input to the surface catchment (Table 2).

SSC data collected during 2009 and 2010 using both single-stage samplers and a depth-integrated sampler were pooled together to form one rating curve for silt/clay $(<63 \mu \mathrm{m})$ and one for suspended sand (>63 $\mu \mathrm{m}$ ) (Figure 6). Single-stage samplers that collected near-surface water samples had SSC values similar to width- and depth-integrated samples, suggesting that suspended sediment was well mixed through the cross-section during turbulent flood conditions (Figure 2b). Total SSC values during runoff events consistently exceeded 10,000 mg/L and peaked greater than 100,000 mg/L. These concentrations are 1 to 2 orders of magnitude more than peak concentrations measured in the nearby Mitchell River during floods ( 1,000 mg/L; Rustomji et al., 2010). In WPGC2a, silt/clay concentration ( $<63 \mu \mathrm{m}$; washload) dominated total SSC and values remained high for low discharges 
and only varied over one order of magnitude. Suspended sand (>63 $\mu \mathrm{m}$; bed material load) increased more rapidly with discharge, spanned three orders of magnitude, and was a more important contributor to total SSC during the highest discharges (i.e., 10-20\%) (Figure 6).

At the event scale, empirical suspended sediment load estimates were dominated by washload $<63 \mu \mathrm{m}$ (90.2\%)(Table 2; Figure 11) originating from the fresh erosion of gully scarps and bare internal gully surfaces. At the annual scale, total suspended sediment load estimates for WY 2009 and WY 2010 (Table 2) were also dominated by washload $<63 \mu \mathrm{m}$ ( $84.5 \%$ and $90.0 \%)$. Conversely, the contribution of suspended bed material $>63 \mu \mathrm{m}$ was low at $10-15 \%$ of the total suspended load (Table 2). However at the highest measured discharges at the event scale, $25 \%$ of the sediment was coarser than $63 \mu \mathrm{m}$ using wet sieving methods (Figure 6; Figure 11). These data differences reflect the event variability of suspended sand with discharge compared to averages over the period of record.

Insert Figure 6 and Figure 7 Approximately Here.

Correlations between 24-hr total rainfall and daily suspended sediment yield (Figure 8) suggested that the export of suspended sediment was intricately linked to the input of rainfall, runoff, and resultant erosion and onward transport. This is supported by daily photographic measurements of sediment supply from scarp retreat driven by direct rainfall erosion and infiltration-excess runoff from above the scarp (Figure 5; Shellberg et al., 2013). However, 24-hr rainfall total is just a proxy metric for a suite of variables driving and influencing internal erosion processes that vary with time, rainfall magnitude and intensity. Below 24-hour rainfall thresholds for scarp retreat ( $\sim 10 \mathrm{~mm})$, direct particle detachment from rain drops on exposed subsoils and erosion from overland flow still co-contributed to measureable sediment yield above a $\sim 2 \mathrm{~mm}$ rainfall threshold (Figure 8). These smaller rainfall-runoff responses were more unpredictable due to variability in rainfall intensity and erosion effectiveness, possible existence of unmeasured hysteresis in Q-SSC rating curves at low discharge, and/or water and sediment measurement error at extremely low discharge.

Insert Figure 8 Approximately Here. 


\subsubsection{Particle size and settling velocity analysis}

The particle size distribution of local bed material (wet sieving) provided support for the $63 \mu \mathrm{m}$ value used as a cut-off between washload and suspended-bed-material load (Figure 9), where only 12\% of the bed material was less than $63 \mu \mathrm{m}$. Additionally during small runoff events when turbulent suspension of sand bed material load was not active in the outlet channel, 95\% of the sediment washed off gully surfaces and transported in suspension was $<63 \mu \mathrm{m}$ (Coulter analysis)( Figure 9).

In comparing particle size results from the Coulter analysis and basic wet sieving during SSC analysis, some inconstancies became apparent for samples where sand was common. For the SSC sample at $0.97 \mathrm{~m}^{3} / \mathrm{s}$, the wet sieve split at $63 \mu \mathrm{m}$ before SSC analysis indicated that $\sim 25 \%$ of the sediment was coarser than $63 \mu \mathrm{m}$ (Figure 6), while the Coulter analysis suggested that $\sim 40 \%$ was coarser than 63 $\mu \mathrm{m}$ (Figure 9). Intuitively the Coulter analysis should result in reduced coarse sediment due to additional aggregate dispersion; however the opposite was true. Despite consistent results from duplicate samples for Coulter analysis, these inconsistencies in different methodologies are likely a result of 1) sand bias during Coulter sub-sampling (several water drops from over $150 \mathrm{~mL}$ of water during intense stirring), and 2) the degree and length of washing samples during wet sieving. Further experimentation will be needed to uncover exact sources of bias by method.

The average particle size distribution of soils from the gully head scarp (Coulter analysis) estimated $60 \%$ of the sediment was finer than $63 \mu \mathrm{m}$ (Figure 9). After erosion from scarp retreat or direct rainfall impacts, the finer fraction is readily exported as washload. The coarser fraction of sand and recently indurated ferricrete and calcrete pisoliths readily settle as lag deposits in gully channels and insetfloodplains, as indicated by their coarser particle size distributions (Figure 9). During peak runoff $\left(0.97 \mathrm{~m}^{3} / \mathrm{s}\right)$, the particle size of suspended sediment closely matched the average distribution of scarp soils (Figure 9). This suggests a direct and inherent connection at the event scale between head-scarp sediment supply and sediment transport in the outlet channel $600 \mathrm{~m}$ away, at least for the finer fractions of sediment. Coarse lags of sand $(>63 \mu \mathrm{m})$ on the gully floor and outlet channel were also suspended during these larger events, but the particle size distribution of suspended sediment was not enriched with sand particles beyond the degree that it already existed in the scarp parent material 
(Figure 9). During smaller discharges, suspended particle sizes lowered toward the fine silt fraction, during which mean settling velocities reduced below $0.0005 \mathrm{~m} / \mathrm{s}$ and water remained concentrated with fine suspended clays (Figure 9; Figure 10).

The relationship between discharge (Q) and mean settling velocity ( $\bar{\phi}$ ) of suspended sediment followed an exponential trend over the measurement range up to $1.0 \mathrm{~m}^{3} / \mathrm{s}$ (Figure 10). The rapid increase in mean settling velocity above $0.8 \mathrm{~m}^{3} / \mathrm{s}$ can largely be attributed to the suspension of sand bed material (> $63 \mu \mathrm{m}$ ) due to increases in bed shear stress, turbulence, and eddy velocity. The slope of the sand rating curve was steeper than the silt/clay curve (Figure 6), with the proportion of sand concentration to the total suspended sediment concentration increasing with discharge. Empirical data are lacking to confirm mean settling velocity characteristics at high discharges ( $\left.>1.0 \mathrm{~m}^{3} / \mathrm{s}\right)$; however it is clear that the exponential trend in Figure 10 will not continue indefinitely with discharge. It is hypothesized that the particle size distribution of the bed material (Figure 9) will represent the maximum range of potential suspended sediment, which when converted to a mean settling velocity ( $\phi$ ) has a value of $0.032 \mathrm{~m} / \mathrm{s}$. Alternatively, additional soil detachment/failure from the gully scarp during extreme events could dilute suspended-sand bed-material and keep $\bar{\phi}$ closer to that of the average scarp soil (Figure 9), which equates to $0.00876 \mathrm{~m} / \mathrm{s}$. Empirically or theoretically predicting mean settling velocity $(\bar{\phi})$ changes with discharge will be important to modelling suspended sediment transport and yield from alluvial channels under transport-limited conditions (Bagnold 1966; Hairsine and Rose 1992; Rose 1993).

Insert Figure 9 and Figure 10 and Table 2 Approximately Here.

\subsection{3.a.1 Bed material load}

Theoretical estimates of total bed material load (bedload + suspended bed material) using methods of Yang (1973) and Ackers and White (1973) and median particles sizes from bed material samples underestimated the potential total bed material load for WPGC2a. This was indicated by theoretical results for total bed material load that were less than measured and empirical estimates of suspended bed material (i.e., suspended sand $>63 \mu \mathrm{m}$ ) (Figure 11). These empirical suspended sand loads did not 
account for the unmeasured bedload and thus were a minimum (Table 2). More sensible estimates using the Yang (1973) model were obtained by calculating weighted bed material concentrations using 12 size fractions of a truncated particle size distribution (>63 $\mu \mathrm{m})$ (Yang 1973; Yang and Wan 1991) (Figure 11; Table 2). These latter results provided a theoretical reference value for sand bed material load using equations and methods often used in the literature.

Insert Figure 11 Approximately Here.

\subsection{3.a.2 Combined estimates for total load}

To estimate total load output of all sediment from WPGC2a, empirical washload estimates were summed with theoretical total bed material load estimates. The resultant total and specific load estimates for WPGC2a (Table 3) were high compared to both Australian and global data on gully erosion (see discussion; Figure 12). The effective specific-yields from the internal gully area (378 to 1,537 t/ha/yr) were much higher than the total catchment specific-yields (89 to $363 \mathrm{t} / \mathrm{ha} / \mathrm{yr}$; Table 3), which is expected from the extreme differences in erosion above and below the scarp. Specific sediment yields estimated from historic air photos were within the same order of magnitude as the recent GPS and gauge data (Table 3). The estimated sediment input from gully scarps (GPS surveys) was 33\% of the gauged output in WY 2009 and 99\% of output in WY 2010 (Table 3). These data are influenced by the inherent measurement error of scarp retreat (Table 1), sediment output (Table 2), and unmeasured internal sediment sources and sinks. However, the low percentage of scarp erosion contribution (33\%) to gauge output in WY 2009 highlights the importance of internal gully sediment sources such as partially eroded internal gully slopes, remnant pedestals, and bank erosion (Figure 1).

Similarly, sediment budgeting at the catchment scale has estimated $154 \mathrm{t} / \mathrm{ha} / \mathrm{yr}$ for the internal gully pixel (271m x 271m) at WPGC2a (Brooks et al., 2008; Rustomji et al., 2010; Shellberg, 2011), derived from the ASTER-satellite estimated gully perimeter, historic catchment median erosion rate from air photos, $1.5 \mathrm{~m}$ scarp depth, and average bulk density of $2000 \mathrm{~kg} / \mathrm{m}^{3}$. These data are less than gauged specific-yields from the internal area, in addition to the internal-gully specific-yields from GPS for WY 2009 and 2010, with the latter due to large differences in estimated gully perimeter and annual 
variation in scarp retreat (Table 3). However at the catchment scale, these satellite and air photo based estimates are reasonable first-order approximations of long-term erosion rates.

Insert Table 3 Approximately Here.

\subsection{Discussion}

\subsubsection{Scarp retreat and sediment supply}

The utilization of both GPS surveys and historic air photos provided a useful temporal measure of changes in alluvial gully area and sediment supply over long scarp distances and different time scales (e.g., Brooks et al. 2009; Shellberg et al. 2010; Shellberg 2011). However, GPS error ( $\pm 50 \mathrm{~cm})$ and overlap between annual surveys suggest that more accurate (but expensive and time consuming) techniques are warranted. Measurement of short-term changes in scarp location, internal gully morphology, and volumetric sediment supply could be measured from repeat surveys by airborne LiDAR, terrestrial LiDAR, and/or large-scale photogrammetry. Gaps in historic air photo time-series and erosion rate estimates could also be filled by other indirect dating techniques for gully erosion, such as tree dating and optically stimulated luminescence dating of stratigraphic layers (Shellberg, 2011).

Gully planform changes often follow negative exponential decay with rapid initial change followed by a longer relaxation period, due to numerous intrinsic or extrinsic factors and complex response (e.g., Graf, 1977; Schumm, 1979; Rutherfurd et al., 1997; Nachtergaele et al., 2002; Vandekerckhove et al., 2003; Thomas, 2004). However, one- or two-dimensional planform changes should be interpreted with caution for hypotheses on sediment yield (i.e., Graf, 1977), as three-dimensional volumetric change is the key metric from a gully evolution and sediment yield perspective. Additional historic air photo data from 18 other alluvial gully complexes across the Mitchell River megafan documented both linear and exponential decay trends in growth rates of gully area and volume (Shellberg et al., 2010; Shellberg, 2011). Linear trends in area and volume growth at WPGC2a, as well as roughly similar specific sediment yields from the scarp and channel outlet historically and recently (Table 3), do suggest that the sediment supply has been relatively consistent and abundant over the historic period 
for this gully. For WPGC2a, this is perhaps due to long relaxation times following initial historical disturbance, highly erodible soils, lack of bedrock or catchment controls, a large relative relief and potential energy, and fairly consistent monsoonal climate (Shellberg, 2011; Shellberg et al., 2013).

Once moisture thresholds were exceeded, 24-hr total rainfall was an important predictor of both scarp retreat and sediment yield at the outlet. Thus, rainfall could be used as an independent variable to model sediment yield from alluvial gullies using distributed catchment models, as long as some inherent geomorphic, edaphic, and hydraulic conditions are known. However, 24-hr total rainfall is just a proxy metric for a whole suite of measured and unmeasured variables influencing erosion. The input of kinetic/momentum energy from rainfall/runoff can detach particles during rain drop impact, slake/disperse soil aggregates, erode sediment during overland flow, and dismantle failed soil blocks for onward fluvial transport, which influence scarp retreat and sediment yield. The remaining variability between rainfall and scarp retreat is likely explained by seasonal variations in vegetative cover and water runoff, and intrinsic thresholds of geotechnical stability such as near-surface porewater pressure, tension-crack development, and antecedent conditions (Shellberg et al., 2013).

\subsubsection{Internal erosion/deposition processes}

Internal erosion and deposition processes within the gully complex below the scarp face highlight the partially or fully transport-limited nature of the sediment yield. Field and LiDAR observations indicate that scarp retreat is often incomplete spatially, with many partially eroded features remaining within the gully complex such as remnant pedestals and uneroded slopes and ridgelines (Figure 1). Thus scarp retreat is a minimum estimate of sediment supply to a gully outlet. Quantitative data suggest that erosion at the head scarp does not always dominate the output of sediment during wet years (WY 2009), but can during dry years at least in net terms (WY 2010). Internal gully sediment sources and sediment storage on gully floors can vary in space and time according to local geomorphic forms, different erosion processes, and variability in rainfall and discharge magnitude.

Depositional features such as gully inset-floodplains develop from coarser lags of sand and ferricrete pisoliths, which can re-erode during bank erosion along the outlet channel. The longitudinal profile of the WPGC2a outlet channel below the active scarp zone is generally linear and appears to be at a 
quasi-equilibrium slope (Figure 4; Shellberg, 2011). However, ongoing changes in sinuosity through bank erosion and avulsion across inset-floodplains suggest that the channel can adjust toward an equilibrium slope in response to the episodic supply and transport of water and coarse sediment. Therefore, internal erosional and depositional features and processes within the gully complex are important in supplying and metering coarse sediment, which warrant further investigation.

\subsubsection{Supply-limited vs. transport-limited conditions}

Overall at the scale of the internal gully area, the highly erodible nature of these alluvial soils once devegetated evidently produced an abundant supply of suspended sediment to the catchment outlet relative to the sediment transport capacity. The empirical data analyzed here document 1) little hysteresis in SSC-Q rating curves, 2) scarp retreat and suspended sediment yield correlated to rainfall input, and 3) an equilibrium channel outlet profile. From these data, it is hypothesized that partially or fully transport-limited conditions (sensu Bravo-Espinosa et al., 2003) predominate along the alluvial gully outlet channel for most grain sizes. Transport-limited conditions likely dominate for lag deposits of coarse sand and ferricrete pisoliths along the gully bed, while the supply and yield of fine suspended sediment is likely closer to equilibrium conditions at the event and annual scale. In contrast above gully head scarps on uneroded floodplains, erosion and sediment supply appeared to be supplylimited (sensu Bravo-Espinosa et al., 2003) due to reduced slope and potential energy, increased soil cohesion and protection by grass cover, and soil surface sealing during intense rainfall. This resulted in the transfer of excess energy and overland flow momentum to the scarp face. Observations of relatively clear runoff above scarps compared to turbid water below suggest that gully scarps are compressed transition zones between sediment supply- and transport-limited conditions.

Along gully channel outlets where conditions are partially or fully transport-limited as supported by little hysteresis in sediment rating curves, sediment transport could be modelled by theoretical equation(s) such as those of Bagnold (1966), Hairsine and Rose (1992), and Rose (1993), which predict the maximum equilibrium suspended sediment concentration at the transport limit during specific discharge conditions. This will be the topic of forthcoming research efforts. 


\subsubsection{Sediment yield}

The modest water and sediment gauging effort at WPGC2a was essential to empirically measure the magnitude of sediment yield from a rapidly eroding alluvial gully. These data will also be useful for calibrating and updating theoretical suspended sediment transport models for transport-limited conditions (e.g., Hairsine and Rose 1992; Rose 1993). Sediment rating curve data and particle size analysis generally supported a single Q-SSC relationship, which provided support for the concept a transport limited system where sediment transport consistently responded to supplied transport capacity. However, additional SSC data on the rising and falling limbs of dozens of discharge events across seasons are needed to strengthen these observations, confirm the complete lack of hysteresis, and better define sediment supply- and transport-limiting conditions at the gully outlet.

The event variability in Q-SSC relationships in gullies and rivers channels can vary from common clockwise hysteresis loops (depletion of supply during event), to less common anticlockwise (delayed supply from distance sources) or single curve (unlimited local supply) relationships (Olive and Rieger, 1985; Williams, 1989; Nistor and Church, 2005). For gullies globally, Q-SSC relationships are complicated by thresholds for specific particle size detachment or motion, seasonal influences (e.g. wetting-drying; freeze-thaw; vegetation cover), episodic or chronic land-use disturbance, antecedent flood or moisture conditions, and changes in sediment sources and erosion processes (i.e., gully head vs. gully side-wall vs. hillslope erosion) (Piest et al., 1975; Olive and Rieger, 1985; de Boer and Campbell, 1989; Oostwoud Wijdenes and Bryan, 2001; Armstrong and Mackenzie, 2002; Nistor and Church, 2005; Fang, 2008). Furthermore, the location and scale of measurement can influence determinations of sediment availability, with small hillslope catchments often being supply limited compared to larger catchments downstream that integrate sediment from the multiple sources nested upstream (Smith and Dragovich 2009; Bartley et al., 2006; Bartley et al., 2010). Thus for more detailed water and sediment yield measurements from alluvial gullies, a more robust hierarchicallynested gauging system is warranted that integrates improved infrastructure such as compound weirs, continuous stage and turbidity (or other surrogate) measurements (Gray and Gartner, 2009), thresholdtriggered pump-samplers for automatic event sampling, additional manual width- and depth-integrated 
SSC and Q measurements, and the calculation of suspended sediment load estimates at the event scale (e.g. Lewis, 1996).

Measured peak suspended sediment concentrations >100 g/L at WPGC2a were higher than commonly reported for Australia (e.g. Olive and Rieger, 1985; Dunkerley and Brown, 1999; Armstrong and Mackenzie, 2002; Bourke, 2002; Bartley et al., 2006; 2010), but these peak values are still well below non-Newtonian hyperconcentrated flow conditions ( $>400 \mathrm{~g} / \mathrm{L}$ or $40 \%$ by weight) (Beverage and Culbertson, 1964). For example, measured concentration in gullied loess terrain in China can average 600g/L and peak well above 1000 g/L (e.g. Huang et al., 2003 and Fang et al., 2008). However, specific sediment yields from the WPGC2a drainage area (88-350 tons/ha/yr) are comparable to other high erosion areas of the world (Figure 12). The large annual rainfall and runoff volumes at WPGC2a in the monsoonal tropics, combined with modestly high SSC values, produced specific sediment yields comparable to average values in loess terrain of China, where unit rainfall and runoff volumes are at least half of those in northern Queensland (Huang et al., 2003 Chen and Cai, 2006; Fang et al., 2008). The specific sediment yields from alluvial gullies in India are more directly comparable to WPGC2a, perhaps due to similar monsoonal climates and alluvial gully geomorphology (Figure 12; Singh and Dubey, 2000).

Insert Figure 12 Approximately Here.

\subsection{Conclusions}

The increase in planform area of an alluvial gully in the lower Mitchell River of Northern Australia has been monitored over five years, and the hydrology and sediment yield over two water years, showing that specific sediment production and yield are comparable to erosional hotspots on the world scale. These types of alluvial gullies are major concentrated sources of sediment to the aquatic environments, and can dominate catchment sediment budgets (Brooks et al. 2008; 2009; Rustomji et al., 2010; Shellberg 2011; Caitcheon et al. 2012).

The relationship between total suspended sediment concentration and discharge displayed little hysteresis, which was also the case for silt/clay and sand components. These data along with 
measurements of highly dispersible soils, scarp retreat and sediment yield correlated to rainfall input, and a graded channel outlet profile, suggest that transport-limited conditions predominate along the alluvial gully outlet channel for most grain sizes. This transport limiting situation holds promise for future modelling efforts using steady state theory to predict suspended sediment concentration at the transport limit during specific discharge conditions (Bagnold 1966; Hairsine and Rose 1992; Rose 1993).

This study identified the need for expanded empirical investigations across a range of alluvial gully types and sizes in the following areas: 1) improved measurements of event sediment supply from scarp retreat and internal gully surfaces, 2) more robust measurements of event water and sediment yield at gully outlets, 3) particle size differentiation at gully scarps for load-by-source analysis, 4) vertical profiles of water velocity, sediment concentration and size distribution over a range of discharges, and 5) investigation of the more complex erosion and transport situation where river backwater and overbank flooding occur (Shellberg et al., 2013). These data will help improve our understanding of sediment erosion, transport mechanisms and sediment yield from complex gully systems, as well as aid the empirical determination of key model parameters such as average settling velocity and the fraction of stream power effective at sediment transport (Bagnold 1966; Rose 1993; Thomas et al. 2004). 


\section{Acknowledgements}

This research is dedicated to the memory, cultural perseverance, and field assistance of Vivian Lane, aboriginal Gugu Mini elder of the central Mitchell River catchment. Access to Wrotham Park field sites was provided by Ian Rush and Jock Warriner, who we thank for their time talking about the challenges of managing the Mitchell landscape for both private and public benefit. Field assistance was provided by John Spencer, Vivian Lane, and Luke and Leon Kingsley, while laboratory assistance was provided by Daniel Borombovits and Kyle Barton. Bob Wasson provided the Australian database on specific sediment yields. Funding was provided by the Australian Government Caring for Our Country program managed by the Northern Gulf Resource Management Group, the Australian Tropical Rivers and Coastal Knowledge (TRaCK) program, and Griffith University. 


\section{References}

Arnold, G., 1997. Grazier experience with Stylosanthes technology. III. Wrotham Park, 1963-1988. Tropical Grasslands, 31: 522-526.

Ackers, P., White, W.R., 1973. Sediment transport: new approach and analysis. Journal of Hydraulics Division, American Society of Civil Engineers 99: 2041-2060.

American Society for Testing and Materials (ASTM), 2002. Standard Test Methods for Determining Sediment Concentrations in Water Samples (Reapproved 2002), D3977-97-Annual Book of ASTM Standards, v. 11.01. ASTM International, West Conshohocken, pp. 395-400.

Armstrong, J.L., Mackenzie, D.H., 2002. Sediment yields and turbidity records from small upland subcatchments in the Warragamba Dam Catchment, Southern New South Wales. Australian Journal of Soil Research 40: 557-579. DOI:10.1071/SR01065.

Avni, Y., 2005. Gully incision as a key factor in desertification in an arid environment, the Negev highlands, Israel. Catena 63: 185-220. DOI:10.1016/j.catena.2005.06.004.

Bagnold, R.A., 1966. An Approach to the Sediment Transport Problem from General Physics. U.S. Geological Survey Professional Paper 422-I, Reston.

Bartley, R., Roth, C.H., Ludwig, J., McJannet, D., Liedloff, A., Corfield, J., Hawdon, A., Abbott, B., 2006. Runoff and erosion from Australia’s tropical semi-arid rangelands: influence of ground cover for differing space and time scales. Hydrological Processes 20: 3317-3333. DOI: 10.1002/hyp.6334.

Bartley, R., Wilkinson, S.N., Hawdon, A.A., Abbott, B.N., Post, D.A., 2010. Impacts of improved grazing land management on sediment yields Part 2: Catchment response. Journal of Hydrology 389: 249-259. DOI:10.1016/j.jhydrol.2010.06.014.

Beverage, J.P., Culbertson, J.K., 1964. Hyperconcentrations of suspended sediment. Journal of the Hydraulic Division, Proceedings of the American Society of Civil Engineers 90: 117-128.

Bourke, M.C., 2002. Suspended sediment concentrations and the geomorphic effect of sub-bankfull 
flow in a central Australian stream. In: Dyer, F.J., Thoms, M.C., Olley, J.M., (Eds.), The Structure, Function and Management Implications of Fluvial Sedimentary Systems, (Proceedings, Alice Springs, 2002), IAHS Publ. 276: 315-324.

Bradford, J.M., Piest, R.F., 1980. Erosional development of valley bottom gullies in the upper midwestern United States. In: Coates D.R., Vitek, J.D. (Eds.), Thresholds in Geomorphology. Allen and Unwin, London, pp. 75-101.

Bravo-Espinosa, M., Osterkamp, W. R., Lopes, V. L., 2003. Bedload transport in alluvial channels. Journal of Hydraulic Engineering, 129: 783-795. DOI:10.1061/(ASCE)07339429(2003)129:10(783).

Brice, J.C., 1966., Erosion and Deposition in the Loess-Mantled Great Plains, Medicine Creek Drainage Basin, Nebraska. U.S. Geological Survey, Professional Paper 352-H: Reston. Brooks, A.P., Spencer, J., Shellberg, J.G., Knight, J., Lymburner, L., 2008. Using remote sensing to quantify sediment budget components in a large tropical river - Mitchell River, Gulf of Carpentaria, In: Schmidt, J., Cochrane, T., Phillips, C., Elliot, S., Davies T., Basher, L. (Eds.), Sediment Dynamics in Changing Environments, (Proceedings, Christchurch, 2008) IAHS Publ. 325: 225-236.

Brooks, A.P., Shellberg, J.G., Spencer, J., Knight, J., 2009. Alluvial gully erosion: an example from the Mitchell fluvial megafan, Queensland, Australia. Earth Surface Processes and Landforms 34: 1951-1969. DOI:10.1002/esp.1883. With 2010 Erratum, Earth Surface Processes and Landforms 35: 242-245. DOI:10.1002/esp.1993.

Brunner, G.W., 2010. HEC-RAS River Analysis System: User Manual Version 4.1, CPD68. U.S. Army Corps of Engineers, Institute for Water Resources, Hydrologic Engineering Center, Davis.

Bufalo, M., Nahon, D., 1992. Erosional processes of Mediterranean badlands - a new erosivity index for predicting sediment yield from gully erosion. Geoderma 52: 133-147. DOI:10.1016/00167061(92)90079-M.

Caitcheon, G.C., Olley, J.M., Pantus, F., Hancock, G. and Leslie, C., 2012. The dominant erosion processes supplying fine sediment to three major rivers in tropical Australia, the Daly (NT), 
Mitchell (Qld) and Flinders (Qld) Rivers. Geomorphology, 151-152: 188-195.DOI:

10.1016/j.geomorph.2012.02.001

Chen, H., Cai, Q., 2006. Impact of hillslope vegetation restoration on gully erosion induced sediment yield. Science in China Series D (Earth Sciences) 49: 176-192. DOI: 10.1007/s11430-005-01774.

Cheng, N.S., 1997. Simplified settling velocity formula for sediment particles. Journal of Hydraulic Engineering, American Society of Civil Engineers 123: 149-152. DOI:10.1061/(ASCE)07339429(1997)123:2(149).

Colby, B.C., 1961. The single-stage sampler for suspended sediment: Report No. 13. In: A Study of Methods Used in Measurement and Analysis of Sediment Loads in Streams. Federal InterAgency Sedimentation Project (FSIP), St. Anthony Falls Hydraulic Laboratory, Field Technical Committee of the Subcommittee on Sedimentation of the Inter-Agency Committee on Water Resource, Minneapolis, Minnesota, pp. 105. http://fisp.wes.army.mil/Report\%2013.pdf Condon, R.W., 1986. A Reconnaissance Erosion Survey of part of the Victoria River District, N.T., Hassall \& Associates, Canberra.

de Boer, D.H., Campbell, I.A., 1989. Spatial scale dependence of sediment dynamics in a semi-arid badland drainage basin. Catena 16: 277-290. DOI:10.1016/0341-8162(89)90014-3.

diCenzo, P.D., Luk, S.H., 1997. Gully erosion and sediment transport in a small subtropical catchment, South China. Catena 29: 161-176. DOI:10.1016/S0341-8162(96)00053-7.

Dunkerley, D., Brown, K., 1999. Flow behaviour, suspended sediment transport and transmission losses in a small (sub-bank-full) flow event in an Australian desert stream. Hydrological Processes 13: 1577-1588. DOI: 10.1002/(SICI)1099-1085(19990815)13:11<1577::AIDHYP827>3.0.CO;2-L.

Edwards, T.K., Glysson, G.D., 1998. Field Methods for Measurement of Fluvial Sediment. Techniques of Water-Resources Investigations for the U.S. Geological Survey, Book 3, Chapter C2, Reston. 
Fang, H.Y., Cai, Q.G., Chen, H., Li, Q.Y., 2008. Temporal changes in suspended sediment transport in a gullied loess basin: the lower Chabagou Creek on the Loess Plateau in China. Earth Surface Processes and Landforms 33: 1977-1992. DOI: 10.1002/esp.1649.

Food and Agriculture Organization (FAO), 2010. World River Sediment Yields Database.

Created by HR Wallingford, UK, for the FAO Land and Water Development Division, Food and Agriculture Organization of the United Nations, Accessed Aug-2010

at http://www.fao.org/landandwater/aglw/sediment/default.asp.

Graf, W.L., 1977. The rate law in fluvial geomorphology. American Journal of Science 277: 178-91. DOI:10.2475/ajs.277.2.178

Gray, J.R., Gartner, J.W., 2009. Technological advances in suspended-sediment surrogate monitoring. Water Resources Research 45: W00D29, DOI:10.1029/2008WR007063.

Gray, J.R., Glysson, G.D., Turcios, L.M., Schwarz, G.E., 2000. Comparability of suspended-sediment concentration and total suspended solids data. United States Geological Survey, Water Resources Investigations Report 00-4191, Reston.

Haigh, M.J., 1984. Ravine erosion and reclamation in India. Geoforum 15: 543-561. DOI:10.1016/0016-7185(84)90024-1.

Hairsine, P.B., Rose, C.W., 1992. Modelling water erosion due to overland flow using physical principles: I. Uniform flow. Water Resources Research 28: 237-243.

Hicks, D.M., Gomez, B., 2003. Sediment transport. In: Kondolf, G.M., Piegay, H., (Eds.), Tools in Fluvial Geomorphology. John Wiley and Sons., West Sussex, pp. 425-461.

Huang, M., Gallichand, J., Zhang, P., 2003. Runoff and sediment responses to conservation practices: Loess plateau of China. Journal of the American Water Resources Association 39: 1197-1207. DOI: 10.1111/j.1752-1688.2003.tb03702.x.

Knighton, A.D., 1998. Fluvial Forms and Processes: A New Perspective. Arnold, London.

Kuhnle, R.A., Bingner, R.L., Alonso, C.V., Wilson, C.G., Simon, A., 2008. Conservation practice effects on sediment load in the Goodwin Creek Experimental Watershed. Journal of Soil and Water Conservation 63: 496-503. DOI: 10.2489/jswc.63.6.496.

Lewis, J., 1996. Turbidity-controlled suspended sediment sampling for runoff-event load estimation. 
Water Resources Research 32: 2299-2310. DOI:10.1029/96WR00991.

Martinez-Casasnovas, J.A., Anton-Fernandez, C., Ramos, M.C., 2003. Sediment production in large gullies of the Mediterranean area (NE Spain) from high-resolution digital elevation models and geographical information systems analysis. Earth Surface Processes and Landforms 28: 443456. DOI: 10.1002/esp.451.

Martinez-Casasnovas, J.A., 2003. A spatial information technology approach for the mapping and quantification of gully erosion. Catena 50: 293-308. DOI:10.1016/S0341-8162(02)00134-0.

Mathys, N., Brochot, S., Meunier, M. and Richard, D., 2003. Erosion quantification in the small marly experimental catchments of Draix (Alpes De Haute Provence, France): Calibration of the ETC rainfall-runoff-erosion model. Catena 50: 527-548. DOI:10.1016/S0341-8162(02)00122-4.

McCloskey, G.L., 2010. Riparian Erosion Morphology, Processes and Causes along the Victoria River, Northern Territory, Australia. Charles Darwin University, PhD Thesis.

McTainsh, G.H., Lynch, A.W., Hales, R., 1997. Particle-size analysis of aeolian dusts, soils and sediments in very small quantities using a Coulter multisizer. Earth Surface Processes and Landforms 22: 1207-1216.

DOI:10.1002/(SICI)1096-9837(199724)22:13<1207::AID-ESP820>3.0.CO;2-K.

Nachtergaele, J., Poesen, J., Oostwoud Wijdenes, D.O., Vandekerckhove, L., 2002. Medium-term evolution of a gully developed in a loess-derived soil. Geomorphology 46: 223-239.

DOI:10.1016/S0169-555X(02)00075-2.

Nearing, M.A., Nichols, M.H., Stone, J.J., Renard, K.G., Simanton, J.R., 2007. Sediment yields from unit-source semiarid watersheds at Walnut Gulch. Water Resources Research 43: W06426: 110. DOI:10.1029/2006WR005692.

Nyssen, J., Poesen, J., Moeyersons, J., Haile, M., Deckers, J., 2008. Dynamics of soil erosion rates and controlling factors in the Northern Ethiopian Highlands - towards a sediment budget. Earth Surface Processes and Landforms 33: 695-711. DOI: 10.1002/esp.1569.

Olive, L.J., Rieger, W.A., 1985. Variation in suspended sediment concentration during storms in five small catchments in southeast New South Wales. Australian Geographical Studies 23: 38-51. DOI: 10.1111/j.1467-8470.1985.tb00477.x. 
Ondieki, C.M., 1995. Field assessment of flood event suspended sediment transport from ephemeral streams in the tropical semi-arid catchments. Environmental Monitoring and Assessment 35: 43-54. DOI: 10.1007/BF02396409.

Oostwoud Wijdenes, D., Poesen, J., Vandekerckhove, L., Ghesquiere, M., 2001. Spatial distribution of gully head activity and sediment supply along an ephemeral channel in a Mediterranean environment. Catena 39: 147-167. DOI:10.1016/S0341-8162(99)00092-2.

Oostwoud Wijdenes, D., Bryan, R., 2001. Gully-head erosion processes on a semi-arid valley floor in Kenya: A case study into temporal variation and sediment budgeting. Earth Surface Processes and Landforms 26: 911-933. DOI: 10.1002/esp.225.

Pain, C.F. and Ollier, C.D., 1992. Ferricrete in Cape York Peninsula, Northern Queensland. BMR Journal of Australian Geology and Geophysics, 13: 207-212.

Payne, A.L., Kubicki, A., Wilcox, D.G., Short, L.C., 1979. A Report on the Erosion and Range Condition in the West Kimberley Area of Western Australia, Department of Agriculture of Western Australia, Technical Bulletin No. 42.

Pickup, G., 1991. Event frequency and landscape stability on the floodplain systems of arid Central Australia. Quaternary Science Reviews 10: 463-473. DOI:10.1016/0277-3791(91)90007-H.

Piest, R.F., Bradford, J.M., Wyatt, G.M., 1975. Soil erosion and sediment transport from gullies. Journal of the Hydraulics Division, Proceedings of the American Society of Civil Engineers 101: 65-80.

Poesen, J., 1993. Gully typology and gully control measures in the European loess belt. In: Wicherek, S. (Ed.), Farm Land Erosion in Temperate Plains Environment and Hills, International Symposium on Farm Land Erosion, Paris France, 25-29 May 1992, Elsevier, Amsterdam, pp. 221-239.

Poesen, J., Valentin, C., Nachtergaele, J., Verstraeten, G., 2003. Gully erosion and environmental change: importance and research needs. Catena 50: 91-133. DOI:10.1016/S03418162(02)00143-1. 
Poesen, J., Vanwalleghem, T., de Vente, J., Knapen, A., Verstraeten, G., Martinez-Casasnovas, J.A., 2006. Gully erosion in Europe. In: Boardman, J., Poesen, J. (Eds.), Soil Erosion in Europe. Wiley, pp. 515-536.

Pringle, H.J.R., Watson, I.W., Tinley, K.L., 2006. Landscape improvement, or ongoing degradation reconciling apparent contradictions from the rangelands of Western Australia. Landscape Ecology 21: 1267-1279. DOI:10.1007/s10980-006-0015-X.

Prosser, I.P., Winchester, S.J., 1996. History and processes of gully initiation and development in eastern Australia. Zeitschrift fur Geomorpholigie Suppl Bnd 105: 91-109.

Rantz, S.E., 1982. Measurement and computation of streamflow. U.S. Geological Survey, Water Supply Paper 2175, Washington D.C.

Rose, C.W., 1993. Erosion and sedimentation. In: Bonell, M., Hufschmidt, M.M., Gladwell, J.S., (Eds.), Hydrology and Water Management in the Humid Tropics: Hydrological Research Issues and Strategies for Water Management. Cambridge University Press, International Hydrology Series, Cambridge, pp. 301-343.

Rustomji, P., Zhang, X.P., Hairsine, P.B., Zhang, L., Zhao, J., 2008. River sediment load and concentration responses to changes in hydrology and catchment management in the Loess Plateau region of China. Water Resources Research 44: W00A04. DOI:10.1029/2007WR006656.

Rustomji, P., Shellberg, J., Brooks, A., Spencer, J., Caitcheon, G., 2010. A catchment sediment and nutrient budget for the Mitchell River, Queensland. A report to the Tropical Rivers and Coastal Knowledge (TRaCK) Research Program. CSIRO Water for a Healthy Country National Research Flagship, Canberra. Available at: http://track.gov.au/publications/registry/876 Rutherfurd, I.D., Prosser, I.P. and Davis, J., 1997. Simple approaches to predicting rates and extent of gully development. In: S.S.Y. Wang, E.J. Langendoen and F.D.J. Shields (Editors), Proceedings of the Conference on Management of Landscapes Disturbed by Channel Incision. The Centre for Computational Hydroscience and engineering. The University of Mississippi, pp. 11241130. 
Schumm, S.A., 1979. Geomorphic thresholds: the concept and its applications. Transactions Institute British Geographers 4: 485 - 515.

Shellberg, J., Brooks, A., Spencer, J., 2010. Land-use change from indigenous management to cattle grazing initiates the gullying of alluvial soils in northern Australia, 19th World Congress of Soil Science, Soil Solutions for a Changing World. (1-6 August 2010), Brisbane, pp. 59-62.

Shellberg, J.G., 2011. Alluvial Gully Erosion Rates and Processes Across the Mitchell River Fluvial Megafan in Northern Queensland, Australia. Griffith University, PhD Thesis, Brisbane, Australia.

Shellberg, J.G., Brooks, A.P., Spencer, J., Ward, D., 2013. The hydrogeomorphic influences on alluvial gully erosion along the Mitchell River fluvial megafan, northern Australia. Hydrological Processes. DOI: 10.1002/hyp.9240

Simpson, C.J., Doutch, H.F., 1977. The 1974 wet-season flooding of the southern Carpentaria Plains, northwest Queensland. BMR Journal of Australian Geology and Geophysics 2: 43-51.

Singh, S., Dubey, A., 2000. Temporal variations in the network of man-impacted gully basins in the sub-humid tropical alluvial riverine environment - A case study of Deoghat gullies of Allahabad District, India. Zeitschrift fur Geomorphologie 44: 175-194.

Smith, H.G. and Dragovich, D., 2009. Interpreting sediment delivery processes using suspended sediment-discharge hysteresis patterns from nested upland catchments, south-eastern Australia. Hydrological Processes, 23: 2415-2426. DOI: 10.1002/hyp.7357.

Thomas, J.T., Iverson, N.R., Burkart, M.R., Kramer, L.A., 2004. Long-term growth of a valleybottom gully, western Iowa. Earth Surface Processes and Landforms 29: 995-1009. DOI: 10.1002/esp.1084.

Vandekerckhove, L., Poesen, J., Oostwoud Wijdenes, D., Gyssels, G., Beuselinck, L., de Luna, E., 2000. Characteristics and controlling factors of bank gullies in two semi-arid Mediterranean environments. Geomorphology 33: 37-58. DOI:10.1016/S0169-555X(99)00109-9.

Vandekerckhove, L., Gyssels, G., Poesen, J., Oostwoud Wijdenes, D., 2001. Short-term bank gully retreat rates in Mediterranean environments. Catena 44: 133-161. DOI:10.1016/S0341- 
8162(00)00152-1.

Vandekerckhove, L., Poesen, J., Govers, G., 2003. Medium-term gully headcut retreat rates in southeast Spain determined from aerial photographs and ground measurements. Catena 50: 329-352. DOI:10.1016/S0341-8162(02)00132-7.

Walling, D.E., Collins, A.L., Sichingabula, H.M., Leeks, G.J.L., 2001. Integrated assessment of catchment suspended sediment budgets: a Zambian example. Land Degradation and Development 12: 387-415. DOI: 10.1002/ldr.461.

Wasson, R.J., 1994. Annual and decadal variation of sediment yield in Australia, and some global comparisons. In: Olive, L.J., Loughran, R.J., Kesby, J.A., (Eds.), Variability in Stream Erosion and Sediment Transport, (Proceedings Canberra 1994). IAHS Publ. 224: 269-279.

Welch, N.H., 1986. Sediment yield from a gully, 4th Federal Interagency Sedimentation Conference. Las Vegas, pp. 3-142 to 3-151. http://pubs.usgs.gov/misc/FISC_1947-2006

Williams, G.P., 1989. Sediment concentration versus water discharge during single hydrologic events in rivers. Journal of Hydrology 111: 89-106. DOI: 10.1016/0022-1694(89)90254-0.

Yadav, R.C., Bhushan, L.S., 2002. Conservation of gullies in susceptible riparian areas of alluvial soil regions. Land Degradation and Development 13: 201-219. DOI: 10.1002/ldr.493.

Yang, C.T., 1973. Incipient motion and sediment transport. Journal of Hydraulic Engineering 99: 1679-1704.

Yang, C.T. and Wan, S., 1991. Comparisons of selected bed-material load formula. Journal of Hydraulic Engineering 117: 973-989. DOI:10.1061/(ASCE)0733-9429(1991)117:8(973).

Yu, B., 2005. Process-based erosion modelling: promise and progress. In: Bonell, M., Bruijnzeel, L.A., (Eds.), Forests, water and people in the humid tropics: past, present and future hydrological research for integrated land and water management. Cambridge University Press, Cambridge, pp. 790-810. 
Changes in WPGC2a gully parameters over time above the gauge location.

\begin{tabular}{|c|c|c|c|c|c|c|c|c|c|c|}
\hline Year & Area & $\left(m^{2}\right)^{a}$ & $\begin{array}{l}\text { Perimeter } \\
\text { (m) }\end{array}$ & $\begin{array}{c}\text { Mean } \\
\text { Retreat } \\
(\mathbf{m} / \mathbf{y r})\end{array}$ & $\begin{array}{c}\text { Max } \\
\text { Retreat } \\
(\mathbf{m} / \mathbf{y r})\end{array}$ & $\begin{array}{c}\text { Gully } \\
\text { Volume } \\
\left(\mathbf{m}^{3}\right)\end{array}$ & $\begin{array}{c}\text { Mean } \\
\text { Gully } \\
\text { Depth } \\
\text { (m) }\end{array}$ & $\begin{array}{c}\text { Tonnes/yr } \\
\text { Scarp } \\
\text { Erosion b } \\
\text { W/ Recent } \\
\text { GPS Data }\end{array}$ & $\begin{array}{c}\text { Tonnes/yr } \\
\text { Scarp } \\
\text { Erosion ab } \\
\text { Long-Term } \\
\text { Photos Only }\end{array}$ & $\begin{array}{c}\text { Annual } \\
\text { Rainfall } \\
(\mathbf{m m})^{\mathrm{c}}\end{array}$ \\
\hline 1949 & 10,491 & $\begin{array}{l}12,726 \\
8,256\end{array}$ & 1,137 & --- & --- & 36,166 & 3.44 & --- & --- & --- \\
\hline 1960 & 21,641 & $\begin{array}{l}24,398 \\
18,884\end{array}$ & 1,391 & 0.80 & 3.50 & 68,203 & 3.15 & 5,926 & 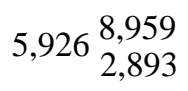 & 986 \\
\hline 2006 & 77,071 & $\begin{array}{l}78,548 \\
75,593\end{array}$ & 3,100 & 0.54 & 2.51 & 172,153 & 2.23 & 4,599 & --- & 952 \\
\hline 2007 & 78,139 & $\begin{array}{l}79,699 \\
76,579\end{array}$ & 3,257 & 0.34 & 10.26 & 174,444 & 2.23 & 4,664 & --- & 1,037 \\
\hline 2008 & 78,506 & $\begin{array}{l}80,263 \\
76,750\end{array}$ & 3,694 & 0.11 & 4.88 & 175,788 & 2.24 & 2,736 & $4,561 \begin{array}{l}5,096 \\
4,026\end{array}$ & 1,217 \\
\hline 2009 & 79,391 & $\begin{array}{l}81,188 \\
77,594\end{array}$ & 3,788 & 0.24 & 6.50 & 177,707 & 2.24 & 3,903 & --- & 1,235 \\
\hline 2010 & 80,106 & $\begin{array}{l}81,810 \\
78,402\end{array}$ & 3,671 & 0.19 & 0.96 & 179,137 & 2.24 & 2,911 & --- & 590 \\
\hline
\end{tabular}

$2 \quad{ }^{\mathrm{a}}$ upper and lower area error margins are $\pm 2 \mathrm{~m}$ historic and $\pm 50 \mathrm{~cm}$ recent, which also translates to error in estimated scarp erosion.

3 b site average bulk density of $2035 \mathrm{~kg} / \mathrm{m}^{3}$.

4 c rainfall data for WY 2008-2010 were measured at WPGC2a; WY 2007 data were estimated for WPGC2a from Australian Bureau of Meteorology

5 (BOM) monthly interpolated 5-km $\left(0.05^{\circ}\right)$ gridded rainfall data, while the average BOM interpolated rainfall was calculated for the periods

6 WY 1950-1960 and WY 1961-2006. 
7 Table $2 \quad$ Summary of rainfall-runoff measurements and sediment load estimates.

\begin{tabular}{|c|c|c|c|}
\hline & $\begin{array}{c}\text { 29-Jan-2010 } \\
\text { to } \\
\text { 30-Jan-2010 }\end{array}$ & WY 2009 & WY 2010 \\
\hline Total Rainfall (mm) & 36.6 & 1235 & 590 \\
\hline Total Runoff $(\mathrm{mm})$ (from 33 ha surface catchment area) & 12 & 327 & 157 \\
\hline Total Runoff $\left(\mathrm{m}^{3}\right)$ & 3855 & 109,213 & 52,501 \\
\hline Runoff Coefficient & 0.33 & 0.26 & 0.27 \\
\hline $\begin{array}{l}\text { Empirical Total Suspended Sediment Load } \\
\text { Tonnes of Sand/Silt/Clay in suspension }\end{array}$ & $206.1 \pm 53 \%$ & $10,931 \pm 63 \%$ & $2,823 \pm 53 \%$ \\
\hline $\begin{array}{l}\text { Empirical Washload }^{\mathbf{a}} \\
\text { Tonnes of Silt/Clay }<63 \mu \mathrm{m} \text { in suspension } \\
\text { (\% total suspended load) }\end{array}$ & $\begin{array}{l}185.8 \pm 51 \% \\
\quad(90.2 \%)\end{array}$ & $\begin{array}{l}9,241 \pm 60 \% \\
\quad(84.5 \%)\end{array}$ & $\begin{array}{l}2,542 \pm 51 \% \\
(90.0 \%)\end{array}$ \\
\hline $\begin{array}{l}\text { Empirical Suspended Bed Material Load } \\
\text { Tonnes Sand }>63 \mu \mathrm{m} \text { in suspension } \\
\text { (\% total suspended load) }\end{array}$ & $\begin{array}{l}20.3 \pm 72 \% \\
(9.8 \%)\end{array}$ & $\begin{array}{l}1,690 \pm 78 \% \\
\quad(15.5 \%)\end{array}$ & $\begin{array}{l}281 \pm 72 \% \\
(10.0 \%)\end{array}$ \\
\hline $\begin{array}{l}\text { Theoretical Bed Material Load } \\
\text { Ackers and White } 1973, \mathrm{~d}_{50}=220 \mu \mathrm{m} \\
\text { (\% Total Load = Washload + Bed Material Load) }\end{array}$ & $\begin{array}{c}4.7 \\
(2.5 \%)\end{array}$ & $\begin{array}{c}608 \\
(6.2 \%)\end{array}$ & $\begin{array}{c}65 \\
(2.5 \%)\end{array}$ \\
\hline $\begin{array}{l}\text { Yang 1973, } \mathrm{d}_{50}=220 \mu \mathrm{m}, \bar{\phi}_{\mathrm{s}}=0.032 \mathrm{~m} / \mathrm{s} \\
(\% \text { Total Load }=\text { Washload }+ \text { Bed Material Load) }\end{array}$ & $\begin{array}{c}6.6 \\
(3.4 \%)\end{array}$ & $\begin{array}{c}623 \\
(6.3 \%)\end{array}$ & $\begin{array}{c}93 \\
(3.5 \%)\end{array}$ \\
\hline $\begin{array}{l}\text { Theoretical Bed Material Load } \\
\text { Yang 1973, Yang and Wan } 1991 \\
\text { By Fraction of Particle Size Distribution > } 63 \mu \mathrm{m} \\
\text { (\% Total Load = Washload + Bed Material Load) }\end{array}$ & $\begin{array}{c}28.9 \\
(13.4 \%)\end{array}$ & $\begin{array}{c}2,747 \\
(22.9 \%)\end{array}$ & $\begin{array}{c}403 \\
(13.7 \%)\end{array}$ \\
\hline
\end{tabular}

$8 \quad$ a upper and lower standard error margins calculated using Equation 1. 
10 Table 3 Summary of total load estimates, specific sediment yields, and sediment

11 production from scarp retreat calculated for the internal gully area (7.8 ha in 2008) and

12 catchment surface area (33 ha).

\begin{tabular}{|c|c|c|c|c|}
\hline & WY 2009 & WY 2010 & $\begin{array}{l}\text { WY 1950- } \\
1960\end{array}$ & $\begin{array}{l}\text { WY 1961- } \\
2006\end{array}$ \\
\hline Gauge Total Load (tonnes/yr) & & & & \\
\hline $\begin{array}{l}\text { Empirical Washload + } \\
\text { Theoretical Bed Material Load (By Size Fraction, } \\
\text { Yang 1973; Yang and Wan 1991) }\end{array}$ & $11,988 \pm 60 \%$ & $2,945 \pm 51 \%$ & --- & --- \\
\hline $\begin{array}{l}\text { Gauge Specific Sediment Yield } \\
\text { (t/ha/yr) Internal Gully Area }=7.8 \text { ha }\end{array}$ & $1,537 \pm 60 \%$ & $378 \pm 51 \%$ & --- & --- \\
\hline $\begin{array}{l}\text { Gauge Specific Sediment Yield } \\
(\mathrm{t} / \mathrm{ha} / \mathrm{yr}) \text { Catchment Surface Area }=33 \text { ha }\end{array}$ & $363 \pm 60 \%$ & $89 \pm 51 \%$ & --- & --- \\
\hline $\begin{array}{l}\text { GPS Scarp Retreat (tonnes/yr) } \\
\text { (\% of input compared to output) }\end{array}$ & $\begin{array}{l}3,903 \\
(33 \%)\end{array}$ & $\begin{array}{l}2,911 \\
(99 \%)\end{array}$ & --- & --- \\
\hline $\begin{array}{l}\text { GPS Scarp Retreat, Specific Sediment Yield } \\
\text { (t/ha/yr) Internal Gully Area }=7.8 \text { ha }\end{array}$ & 500 & 373 & --- & --- \\
\hline $\begin{array}{l}\text { GPS Scarp Retreat, Specific Sediment Yield } \\
\text { (t/ha/yr) Catchment Surface Area }=33 \mathrm{ha}\end{array}$ & 118 & 88 & --- & --- \\
\hline $\begin{array}{l}\text { Air Photo Scarp Retreat, Specific Sediment Yield } \\
\text { (t/ha/yr) Internal Gully Area }=7.8 \mathrm{ha}\end{array}$ & --- & --- & 760 & 585 \\
\hline $\begin{array}{l}\text { Air Photo Scarp Retreat, Specific Sediment Yield } \\
(\mathrm{t} / \mathrm{ha} / \mathrm{yr}) \text { Catchment Surface Area }=33 \mathrm{ha}\end{array}$ & --- & --- & 180 & 138 \\
\hline $\begin{array}{l}\text { Long-term Scarp Specific Sediment Yield (t/ha/yr) } \\
\text { Brooks et al. (2008) for WPGC2a gully pixel ( } 271 \mathrm{~m} \\
\text { x } 271 \mathrm{~m}) \text {. ASTER scarp perimeter x historic } \\
\text { catchment median erosion rate }(0.34 \mathrm{~m} / \mathrm{yr}) \text { x scarp } \\
\text { depth }(2.0 \mathrm{~m}) \text { x bulk density }\left(2000 \mathrm{~kg} / \mathrm{m}^{3}\right) \text {. }\end{array}$ & --- & --- & 154 & 154 \\
\hline
\end{tabular}



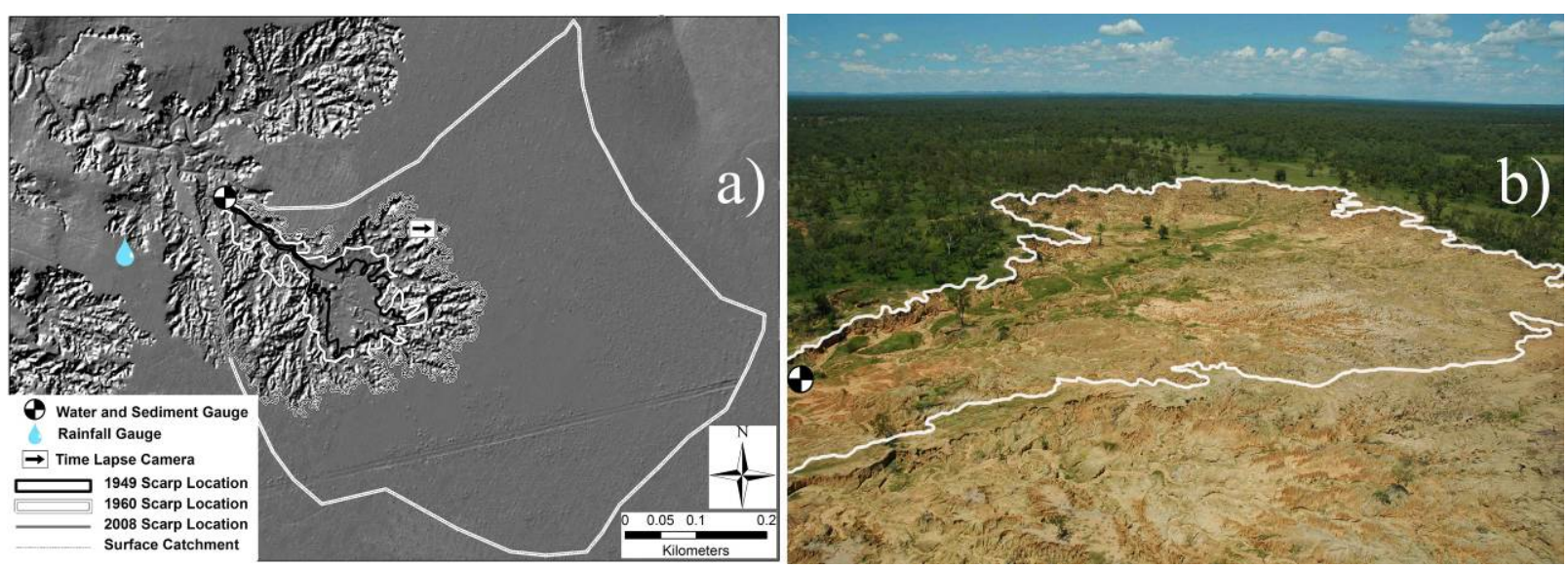

16

17

Figure 1

a) Planform map with LiDAR hillshade showing the surface catchment area,

18 key gully features, and a linear fenceline, and b) oblique overview of WPGC2a catchment with 19 gully scarp boundary highlighted.
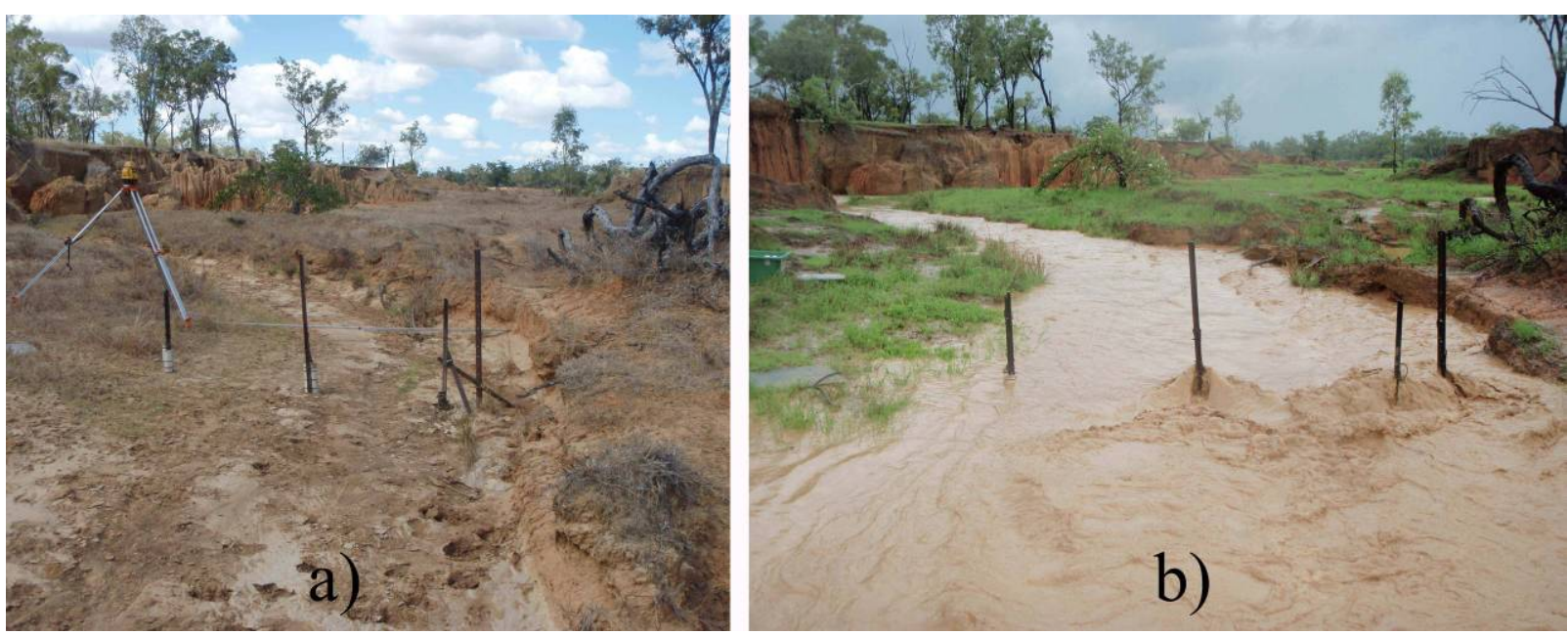

Figure 2

Cross-section at WPGC2s gauge station during the a) dry season, and b) wet season. 


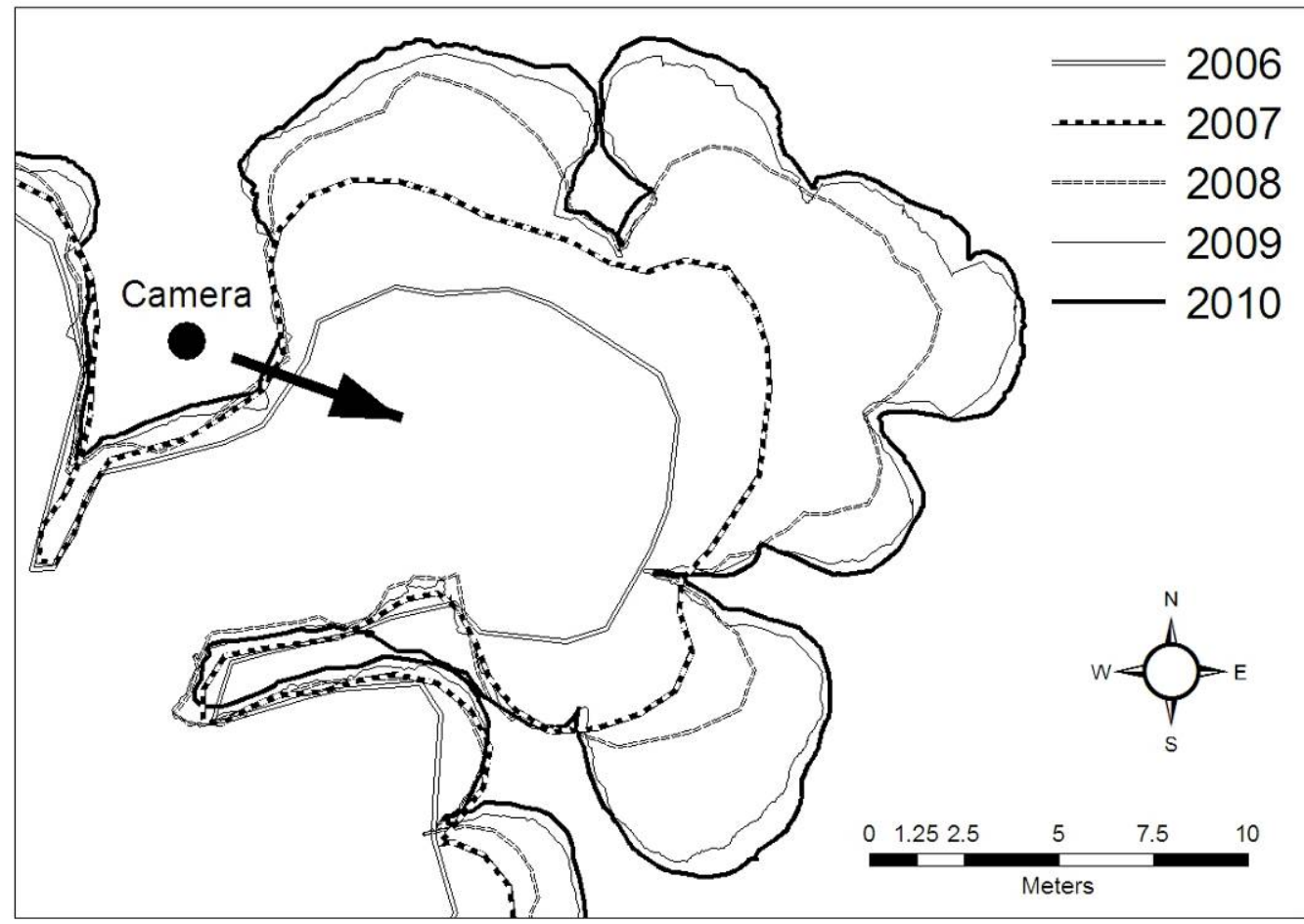

Figure 3 Gully planform area change measured with GPS at the time-lapse camera index site (see Figure 1a for location). The perimeter of this index scarp section (small gully lobe) represents $100 \mathrm{~m}$ or $2.7 \%$ of the total $3700 \mathrm{~m}$ scarp perimeter of WPGC2a.

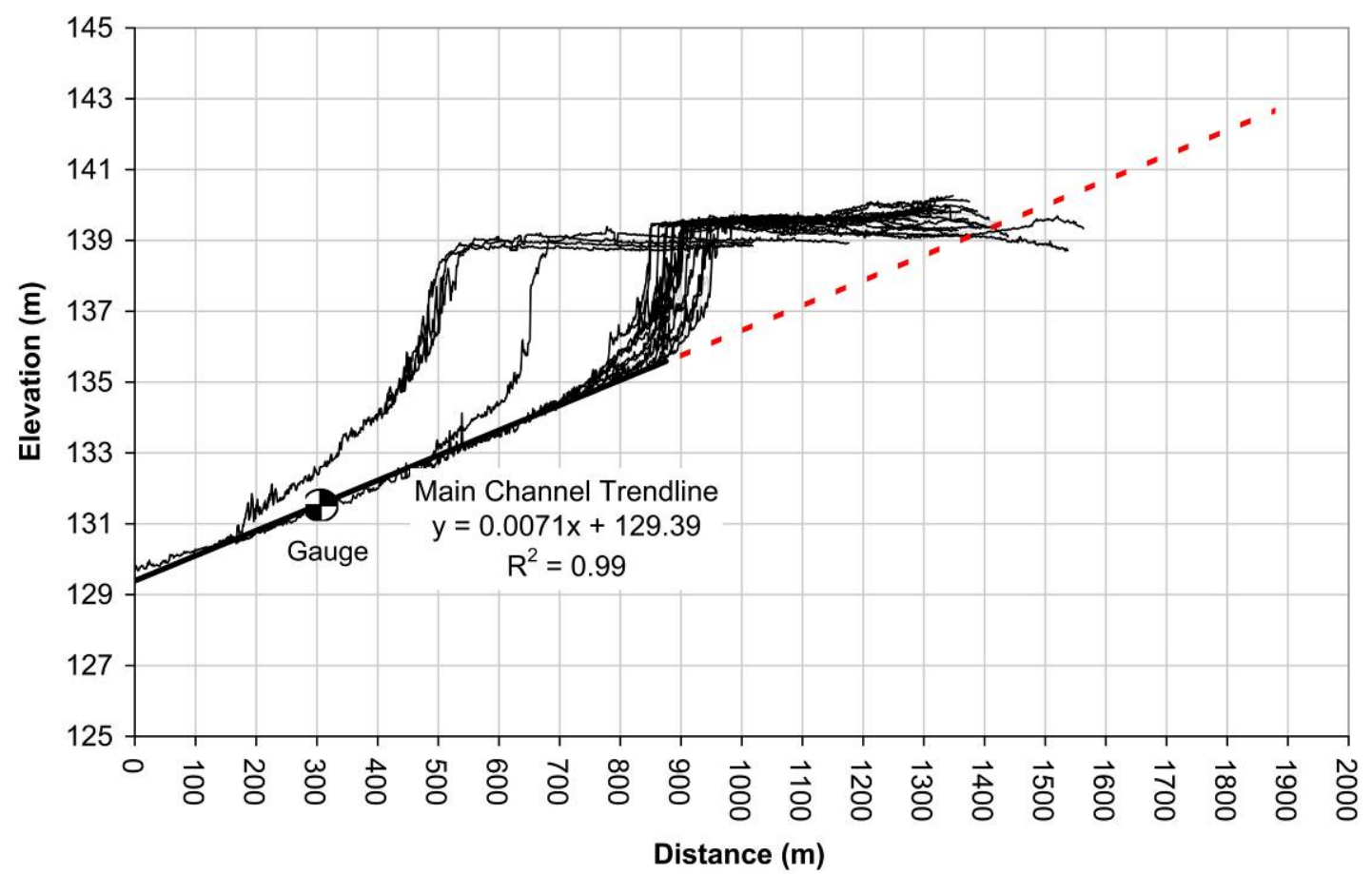

Figure $4 \quad$ Longitudinal profiles of the main channel thalweg and major tributary channels of WPGC2a derived from 2008 LiDAR data. The main channel trendline was fit to the thalweg profile up to the base of the head scarp, beyond which is was extrapolated toward the high

35 floodplain to highlight the future erosion wedge. 


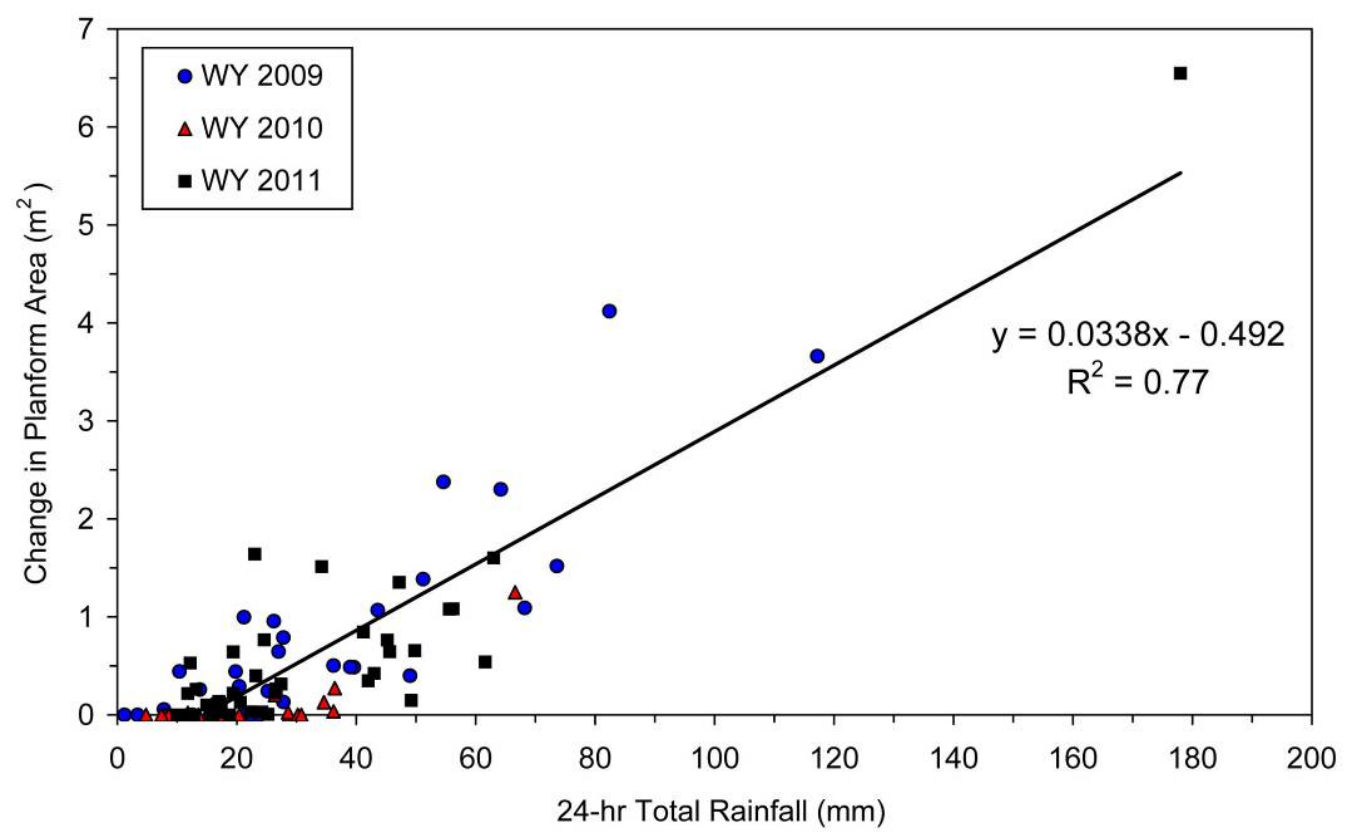

Figure 5 Correlation between estimated daily change in planform area $\left(\mathrm{m}^{2}\right)$ from timelapse photographs and 24-hr total rainfall at the WPGC2 gully index scarp section (see Figure 1a for location) (modified with permission from Shellberg et al., 2012).

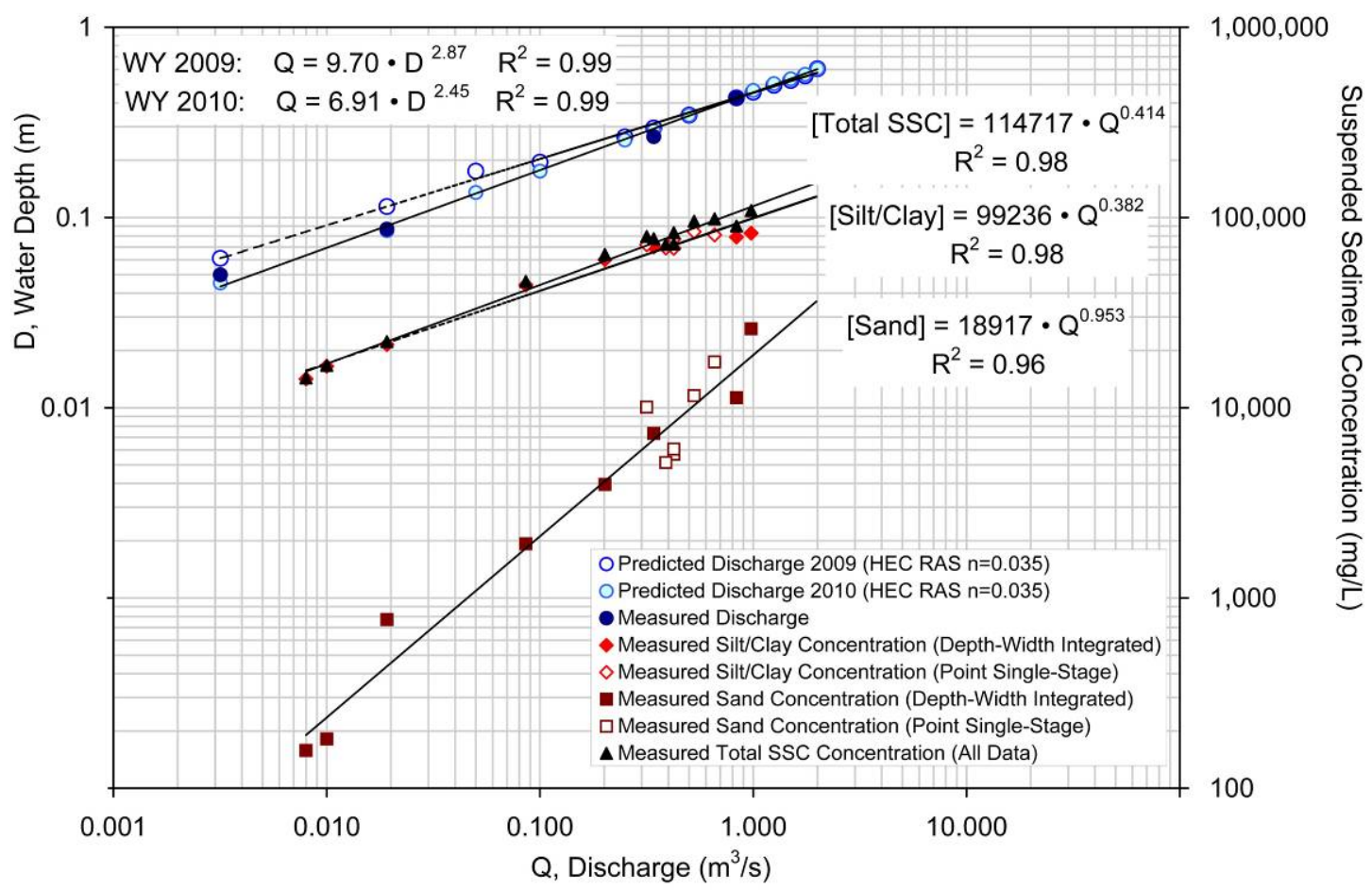

Figure $6 \quad$ Rating curves at gauge station between 1) water depth (D) and discharge (Q) for WY 2009 and 2010, 2) Q and suspended silt/clay concentration, 3) Q and suspended sand concentration, and 4) Q and total suspended sediment concentration (SSC) for both years combined. 


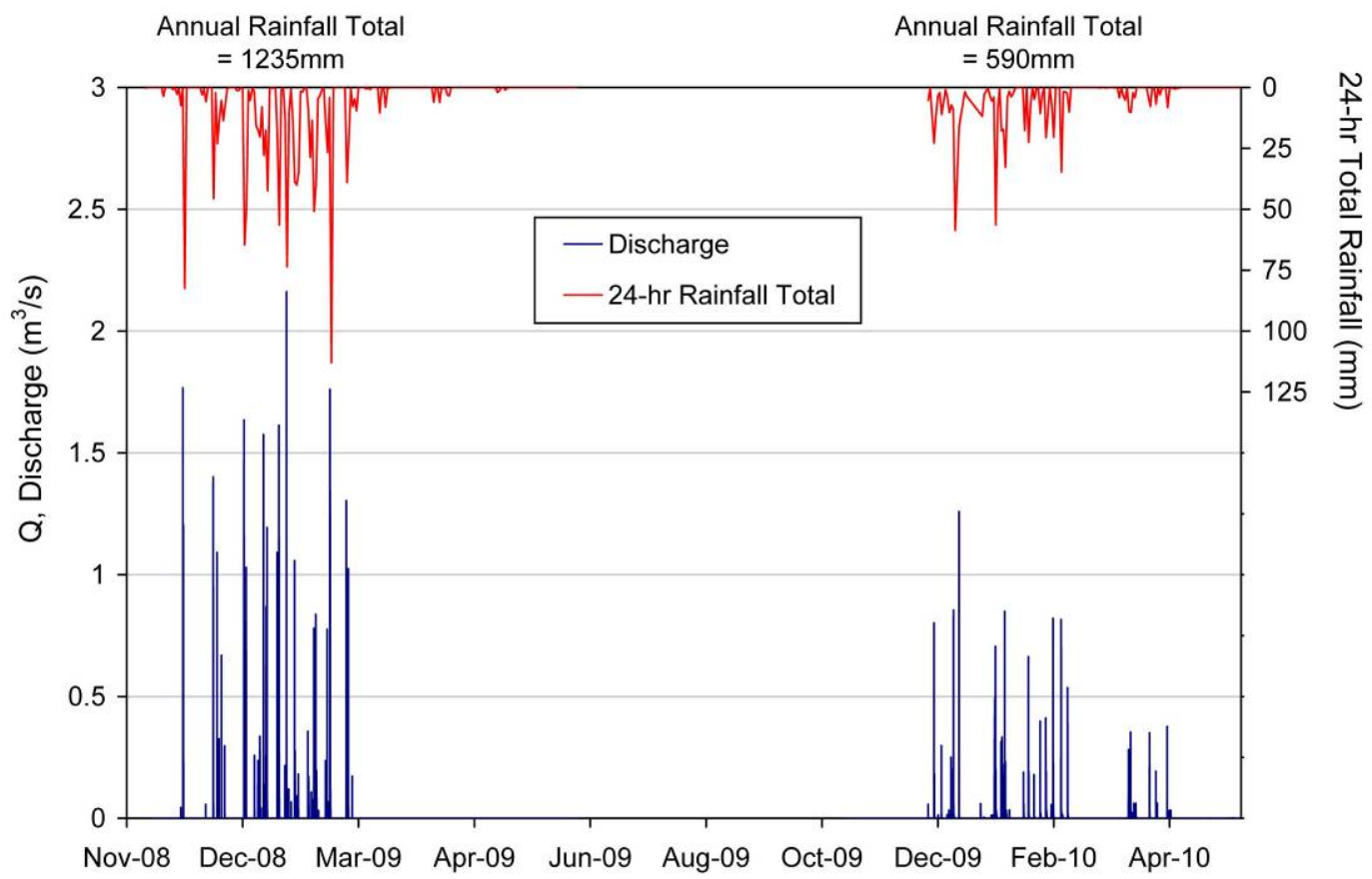

Figure $7 \quad$ Measurements of discharge and rainfall over study period.

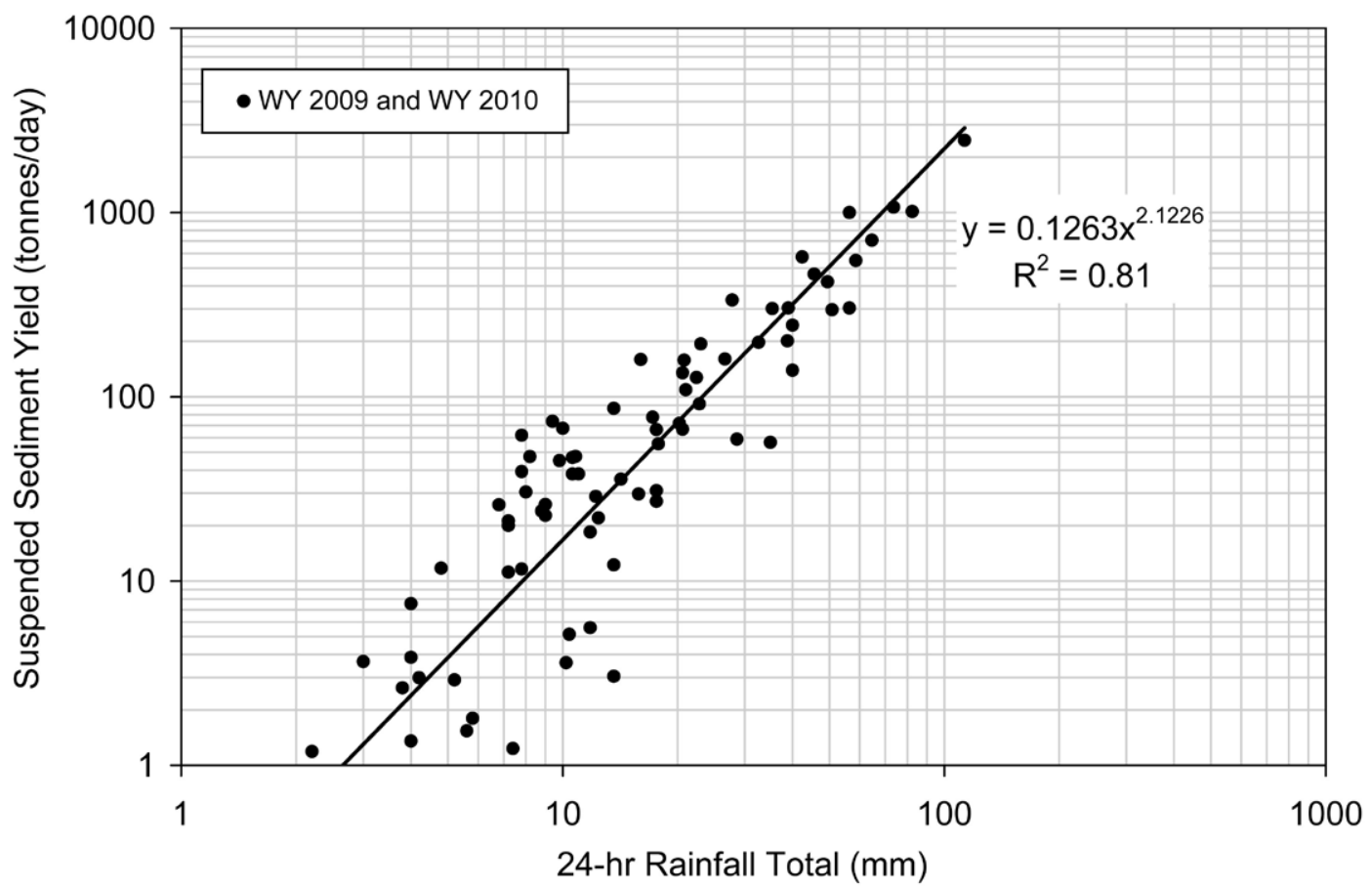

Figure $8 \quad$ Correlation between local 24-hr total rainfall and daily suspended sediment 52 yield at the catchment outlet estimated from D-Q-SSC rating curves in Figure 6 for WY 2009 53 and WY 2010. 


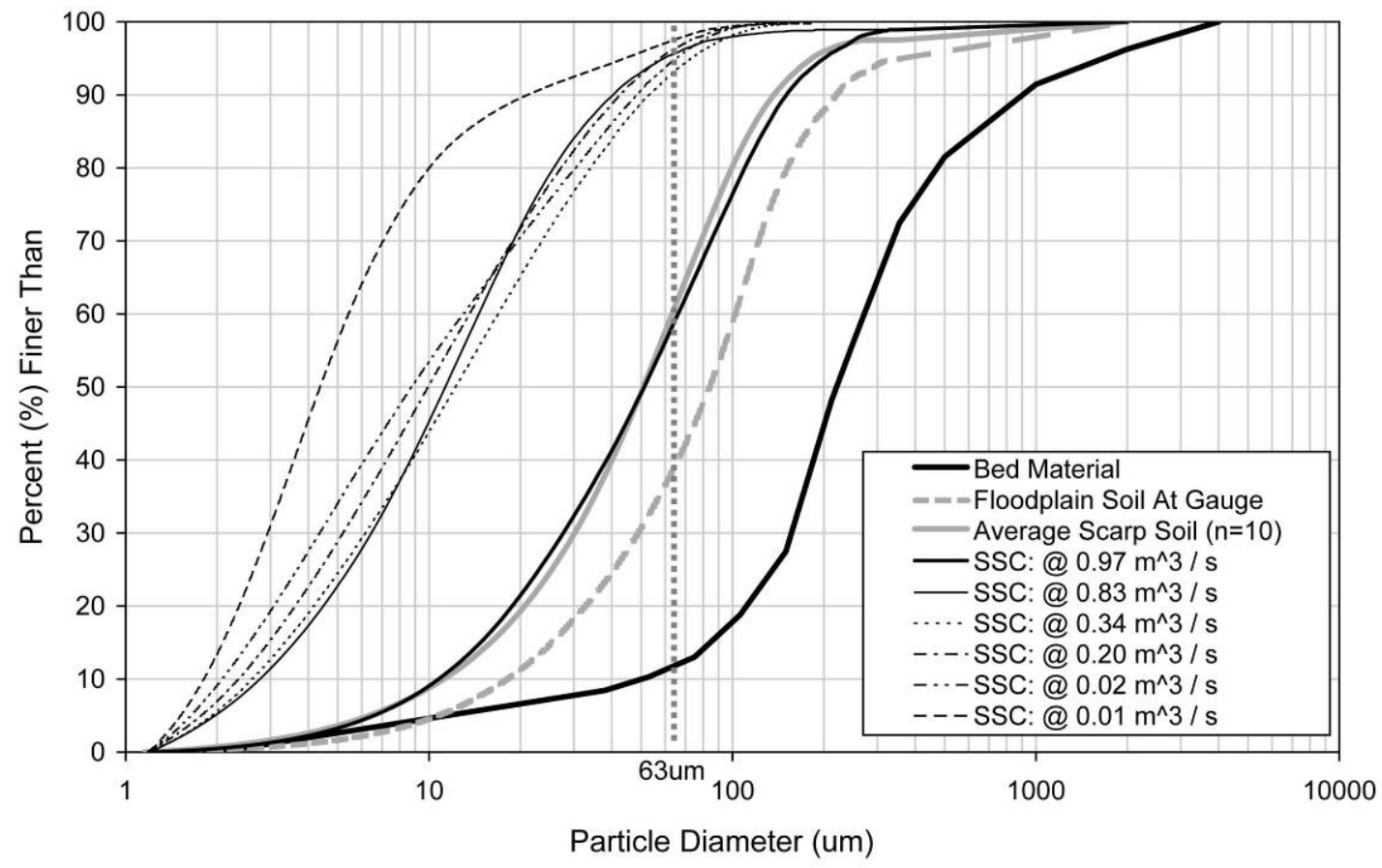

Figure 9 Particle size distributions measured using a Coulter Multisizer for fine soil and suspended sediment material and wet sieving for channel bed material.

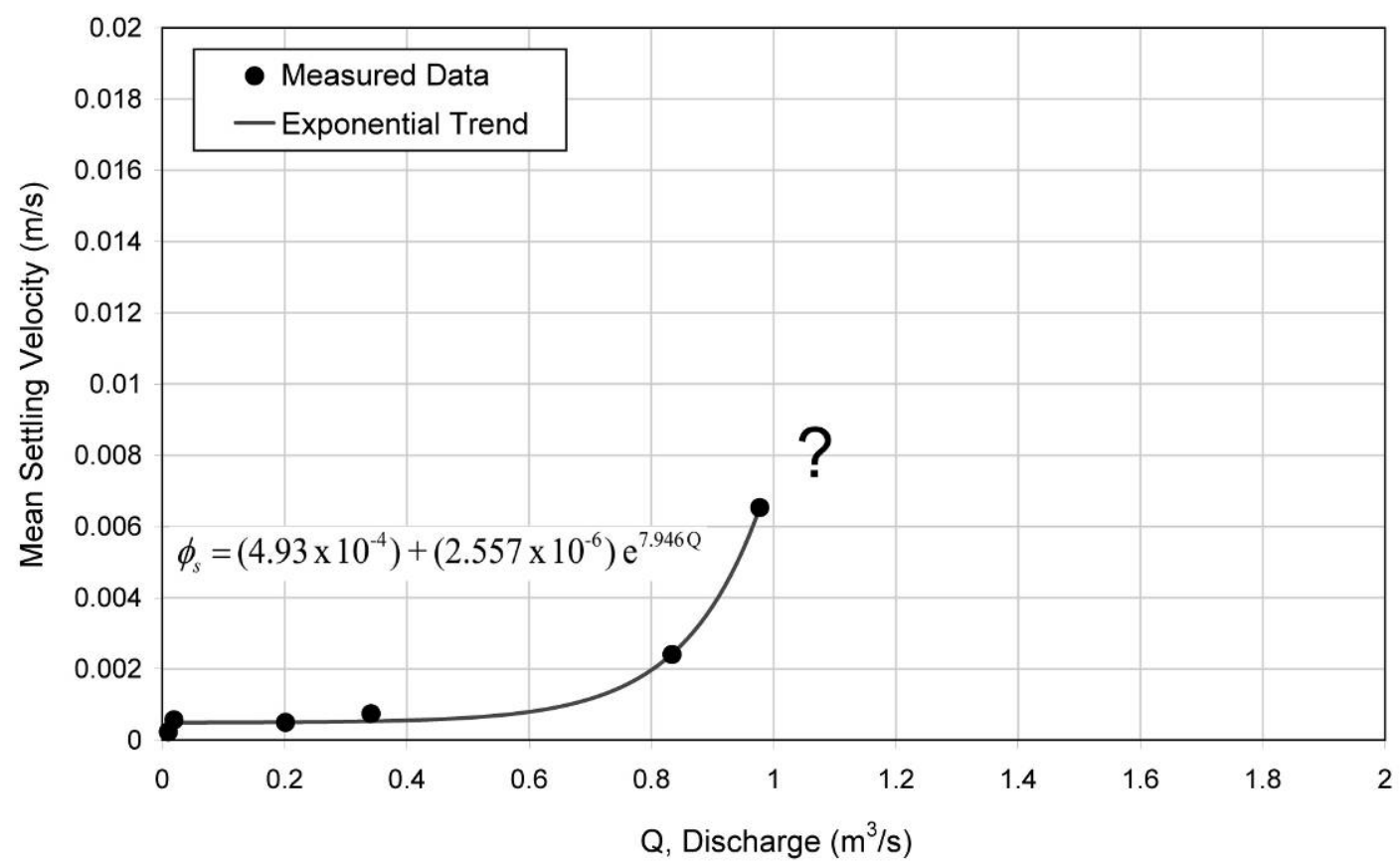

Figure $10 \quad$ Empirical relationship between measured discharge (Q) and the measured mean settling velocity $(\bar{\phi})$ of suspended sediment during several flood events in WPGC2a, without extrapolation of the trend beyond $1 \mathrm{~m}^{3} / \mathrm{s}$ due to a lack of supporting empirical data. 


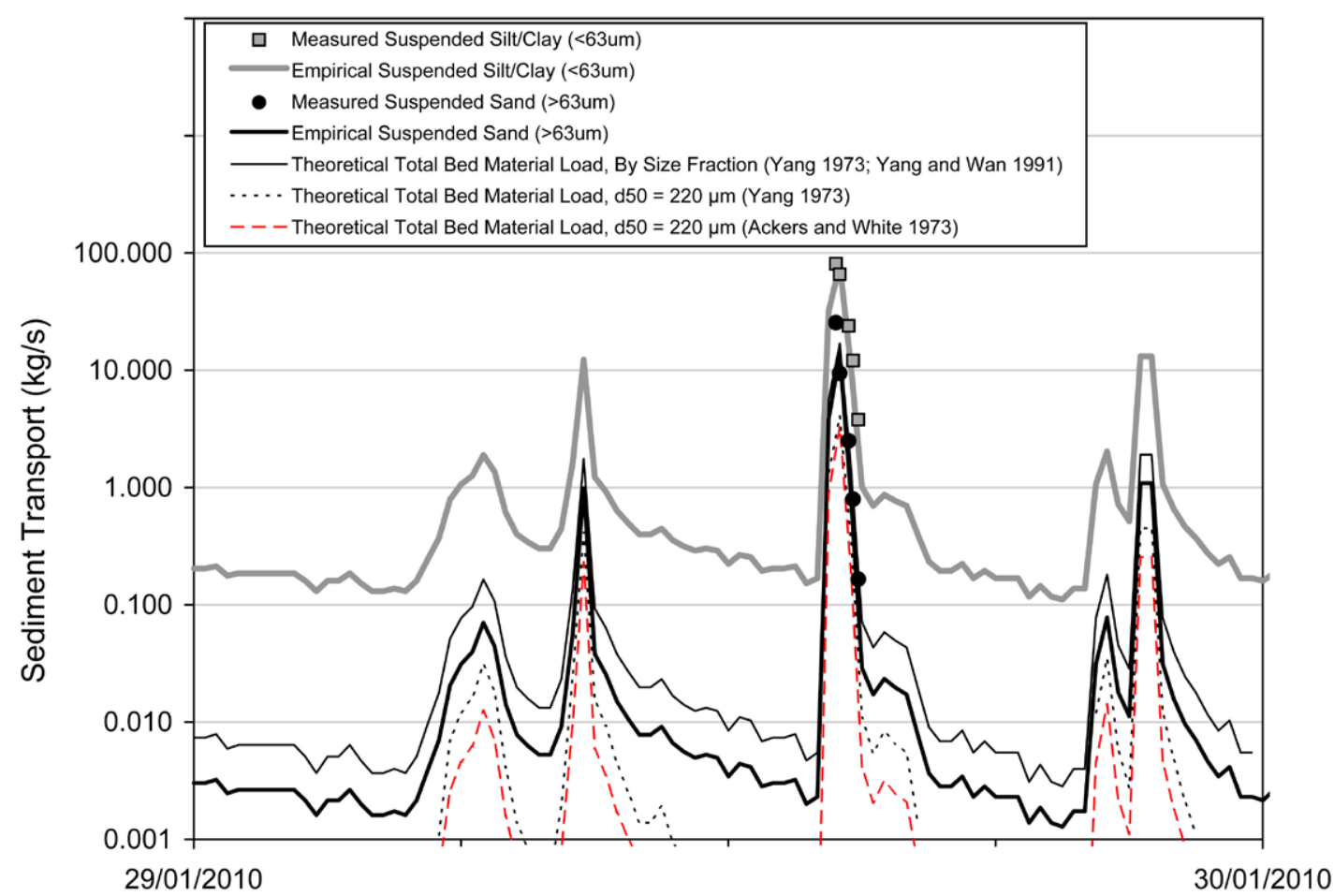

Figure 11 Comparison of point measurement and empirical (rating curve) estimates of suspended silt/clay $(<63 \mu \mathrm{m})$ and sand $(>63 \mu \mathrm{m})$ loads $(\mathrm{kg} / \mathrm{s})$ for 29 January 2010, in addition to theoretical total bed material loads (Ackers and White, 1973; Yang, 1973; Yang and Wan 1991). Final theoretical total bed material loads were estimated from Yang 1973 and Yang and Wan 1991 by calculating concentrations and loads by size fractions for a particle size 69 distribution truncated at $>63 \mu \mathrm{m}$. 


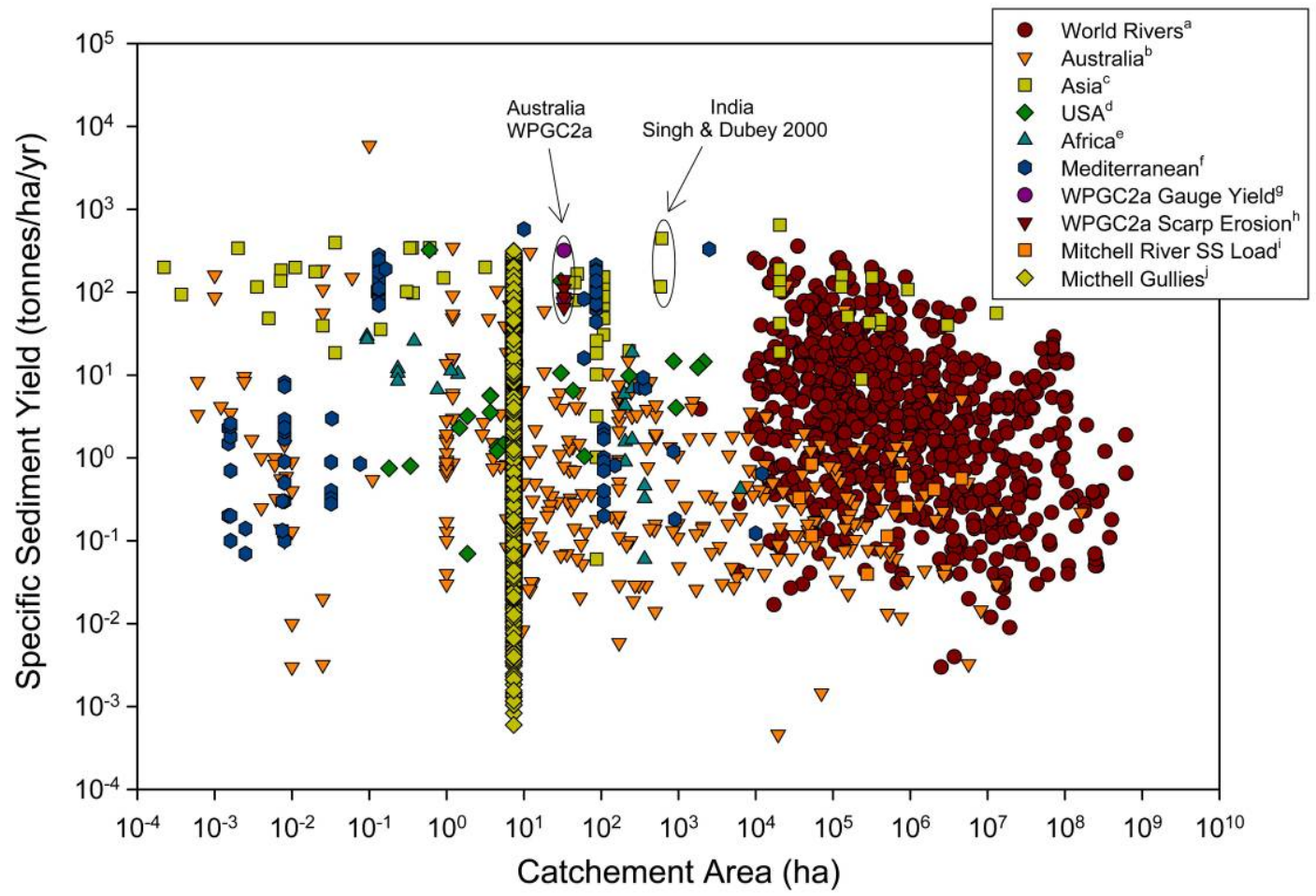

Figure 12 Comparison of specific sediment yields ( $\mathrm{t} / \mathrm{ha} / \mathrm{yr}$ ) by catchment area (ha) for hillslope erosion plots, small gully catchments, small stream catchments, and larger rivers from the following data sources. World Rivers ${ }^{\mathbf{a}}$ (FAO, 2010), Australia ${ }^{\mathbf{b}}$ (plot, gully, stream, river database of Wasson, 1994; review by Prosser and Winchester, 1996; Armstrong and Mackenzie, 2002), Asia ${ }^{\mathbf{c}}$ (diCenzo and Luk, 1997; Singh and Dubey, 2000; Huang et al., 2003; Yu, 2005; Chen and Cai, 2006; Fang et al., 2008; Rustomji et al., 2008), USA ${ }^{\mathbf{d}}$ (Piest et al., 1975; Welch, 1986; Thomas, 2004; Nearing et al., 2007; Kuhnle et al., 2008), Africa ${ }^{\mathbf{e}}$ (Ondieki, 1995; Oostwoud Wijdenes and Bryan, 2001; Walling et al., 2001), Mediterranean (Seginer, 1966; Bufalo and Nahon, 1992; Oostwoud Wijdenes et al., 2000; Mathys et al., 2003; Martinez-Casasnovas, et al., 2003; Martinez-Casasnovas, 2003; Avni, 2005; Nyssen et al., 2008), WPGC2a Gauge Yield ${ }^{\mathbf{g}}$ (this study using 33ha catchment area, Table 3), WPGC2a Scarp Production $^{\mathrm{h}}$ (this study, production estimates using 33ha catchment area, Table 1), Mitchell River SS Yield (fine suspended washload only from surface TSS data, Queensland Department of Natural Resources database), Mitchell Gully Production ${ }^{\mathbf{j}}$ [pixel (271m x 271m) based sediment production from Brooks et al. $(2008,2009)$ across the Mitchell megafan, using $2000 \mathrm{~kg} / \mathrm{m}^{3}$ for catchment average bulk density]. 